\title{
The Judicial Resolution of Church Property Disputes: Canadian and American Models
}

\author{
ALVIN J. ESAU*
}

This article examines the jurisprudence on church property entitlements in the context of membership disputes at Hutterite colonies. The author explores the approaches that Canadian and American courts have taken in dealing with competing claims to church assets held in trust for the use of the members. When faced with allocation issues, Canadian courts have focused on the terms of the trust to determine which faction of the religious association most closely falls within the scope of the trust. By way of contrast, American courts have been more conscious about the separation of church and state and have employed the following models for adjudicating church property dispules: (I) polity-deference. (2) neutral-principles, and (3) the abstention model. The author concludes that the gap between the Canadian and American approaches is not as wide as it may initially appear.
Cet article examine la jurisprudence relative aux droits à la proprièté de l'Église dans le contexte des conflits de membership dans les colonies huttérites. L'auteur explore les démarches que les cours canadiennes et américaines ont adoptées pour régler les nombreuses réclamations à l'ëgard de propriétés que l'Église a en fiducie pour l'utilisation de ses membres. Confrontées $\dot{a}$ des questions d'adjudication, les cours canadiennes se sont concentrées sur les conditions de la fiducie pour déterminer la faction de l'association religieuse qui correspondait le mieux à la portée de la fiducie. Les cours americaines ont au contraire été plus conscientes de la séparation entre l'Éat et I'Eglise et ont utilisé les modeles suivants pour régler les conflits de propriété de l'E்glise: (l) déférence politique. (2) principes de neutralite, et (3) l'abstention. L'auteur conclut que lëcart entre les dèmarches canadiennes et américaines n'est pas aussi grand qu'il peut sembler à prime abord.

\section{TABle of Contents}

I. INTRODUCTION ....................... 768

II. THE JUdiClal RESOlUtion OF CHURCH PROPERTY

DisPUTES IN CANADA . . . . . . . . . . . . . . . . 771

A. EXPRESS AND IMPLIED DOCTRINAL AND/OR

AFFILIATION TRUSTS . . . . . . . . . . . . . . . . 772

B. CRITICISM OF IMPLIED ORIGINALIST

Doctrinal TRUSTS . . . . . . . . . . . . . . . . . . 776

C. CANADIAN DECISIONS ON FINDING AND

ENFORCING EXPRESS AND IMPLIED TRUSTS . . . . . . . 777

D. FROM TRUST DOCTRINE TO REVIEW OF

CORPORATE GOVERNANCE . . . . . . . . . . . . . . . 794

III. The Judicial Resolution of Church Property

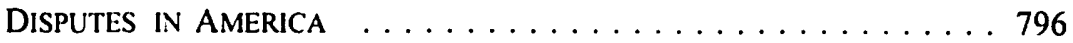

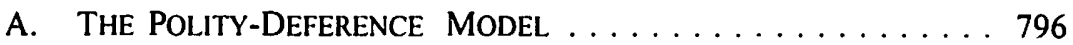

B. THE NeUtrRAL-PRINCIPLES MODEL $\ldots \ldots \ldots \ldots \ldots \ldots 804$

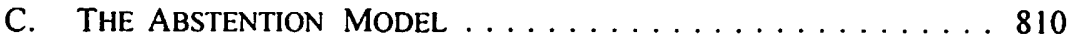

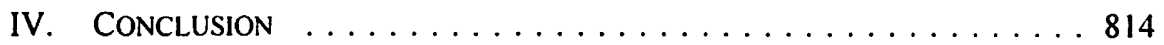




\section{INTRODUCTION}

I have been engaged for some time in an examination of the litigation of membership and property disputes at Hutterite colonies, particularly in Manitoba.' Property entitlements are often linked to membership issues because the property of religious associations is usually held in trust for the beneficial use of members of the particular association. Thus in Hofer v. Hofer, ${ }^{2}$ the Supreme Court of Canada upheld the excommunication of a number of Hutterites at a Manitoba colony who had switched their religious faith from the Hutterite Church to the Radio Church of God. Once their expulsion from membership was affirmed, the court upheld the basic principle that the former members had no property claim to a pro rata share of the colony assets. More recently, the Supreme Court judicially reviewed the expulsion of a number of Hutterites on the ground of insubordination at another Manitoba colony. ${ }^{3}$ The court asserted that when voluntary associations expel members, the court may judicially review the process to ensure that the association has first followed its own internal rules, whether customary or written, and then secondly that the process complies with the basic principles of natural justice in terms of notice and fair opportunity to be heard by an unbiased tribunal. The court voided the expulsion of the Hutterites because they allegedly had not been given adequate notice that their expulsions would be considered at a meeting of members. Following this decision, the colony in question simply returned to the drawing board, gave proper notice, and then proceeded to expel the members again. A Manitoba court upheld these expulsions and applied the basic principle that, so long as the expulsions were valid, the ex-members had no claim to any pro rata share of the assets of the colony, even though they had lived their whole lives on the colony. ${ }^{4}$

However, the second round of the Lakeside ${ }^{5}$ case also dealt with the authority of the majority to expel the minority and was related to a considerable amount of additional Hutterite litigation that arose as a result of a schism in the Schmiedeleut branch of the Hutterite Church, ${ }^{6}$ which occurred after the Supreme Court decision. The immediate

1 See A. Esau. "Communal Property and Freedom of Religion" in J. McLaren \& H. Coward, eds.. Religious Conscience, the State, and the Law: Historical Contexts and Contemporary Significance (Albany: State University of New York, 1999) 97; A. Esau, "Law and Property: The Establishment and Preservation of Mennonite Semi-Communalism in North America: 1870-1925," Colloquium on Property Rights in the Colonial Imagination and Experience. Faculty of Law, University of Victoria, 2001 [forthcoming]; and A. Esau, The Courts and the Colonies [forthcoming].

[1970] S.C.R. 958.

Lakeside Colony of Hutterian Brethren v. Hofer, [1992] 3 S.C.R. 165 [hereinafter Lakeside].

Lakeside Colony of Hutterian Brethren v. Hofer (1994), 93 Man. R. (2d) 161 (Man. Q.B.) [hereinafter Hofer].

Ibid.

Traditionally the Hutterite Brethren Church in North America has consisted of three tribes: the Schmiedeleut. the Darius-Leut, and the Lehrer-Leut. All the colonies in Manitoba were traditionally a part of the Schmiedeleut tribe. For basic background on Hutterites, see V. Peters. All Things Common: The Hutterian Way of Life (New York: Harper \& Row, 1971): J. Hostetler. Hutterite Society (Baltimore: Johns Hopkins University Press, 1974); K.A. Peter, The Dynamics of Hutterite Society: An Analytic Approach (Edmonton: University of Alberta Press, 1987); J. Hofer, The History of the Hutterites (Altona: Friesen \& Sons, 1988); S. Hofer, The Hutterites: Lives and Images of a Communal People (Saskatoon: Hofer Publishers, 1998). 
schism related to a basic disagreement as to whether the Senior Elder of the tribe had been voted out of office. Under that dispute lay a host of controversies related to the Schmiedeleut affiliation with the Bruderhof, a small group of Christian communalists centred in the Eastern United States with arguably more liberal cultural norms, and yet more authoritarian leadership styles as compared to the traditional Hutterites. ${ }^{7}$ There was also a host of allegations relating to various financial transactions involving the Senior Elder and other Hutterite managers and the alleged violations of the traditional anti-litigation norm of Hutterites. ${ }^{8}$ Today, there are about one hundred Hutterite colonies in Manitoba, which before the schism would have been associated as one branch of the wider Hutterian Brethren Church, but are now almost evenly divided into two separate groups, which I call Group One (those that supported the Senior Elder) and Group Two (those who claimed the Elder had lost a vote of confidence at a meeting of the wider Schmiedeleut Conference). During the course of the schism, various colonies were sometimes internally divided, with two opposing groups attempting to gain or retain control of the colony assets. Ultimately, the courts in Manitoba were engaged with disputes at the following colonies: Oak Bluff, ${ }^{9}$ Rock Lake, $^{10}$ Huron, ${ }^{11}$ Cypress, ${ }^{12}$ and Sprucewood. ${ }^{13}$

When a few members of a religious group allegedly switch religions or are deemed by some hierarchy or by some majority vote of a congregation to have violated some norm of the group, it may not seem all that controversial to suggest that a court may enforce the expulsion of the ex-members from the use of the group's community property. However, when a religious schism occurs and involves large groups on both sides, the traditional approach of the courts in determining an all-or-nothing property entitlement raises some obvious questions about the state of the law in regard to church property. Similarly, when the courts award all the property to a small minority on the ground that the larger majority has breached the affiliation or doctrinal trust on which the property must be held, the adequacy of the law may again come into question. In the wake of the schism in the Schmiedeleut, the highest level of the Hutterite Brethren Church, composed of all three tribes, passed a new Constitution and recognized Group Two as the true representatives of the Schmiedeleut. ${ }^{14}$ Group One, on the other hand, argued that the passing of the new Constitution was irregular and that they were the

For background on the Bruderhof, see Y. Oved, The Witness of the Brothers: A History of the Bruderhof (New Brunswick: Transaction Publishers, 1996); B. Zablocki, The Joyful Community: an account of the Bruderhof, a communal movement now in its third generation (Chicago: University of Chicago Press. 1971); J.H. Rubin, The Other Side of Joy: Religious Melancholy Among the Bruderhof (New York: Oxford University Press, 2000).

* The details of the schism are reconstructed in Esau, Courts and Colonies, supra note 1.

" Maendel v. Maendel, Cl 91-01-56943 (1991) Winnipeg (Man. Q.B.).

10 Precision Feeds v. Rock Lake Colony (1994), 93 Man. R. (2d) I (Q.B.). There are a variety of reported decisions dealing with motions and appeals in the case. See (1994), 93 Man. R. (2d) 10 and 13 (Q.B.): (1994). 92 Man. R. (2d) 292 (C.A.); and [1994] M.J. No. 450 and 703 (Q.B.). online: QL (CJ).

1 Royal Bank v. Huron Colony, Cl 94-01-79789 (1994) Winnipeg (Man. Q.B.).

1: Hofer v. Wollmann, Cl 94-01-85797 (1994) Winnipeg (Man. Q.B.).

1" Wollman v. Wollman, Cl 95-01-87332 (1995), Winnipeg (Man. Q.B.).

if Constitution of the Hutterian Brethren Church and Rules as to Community of Property (21 July 1993) [on file with the author] [hereinafter Constitution of the Hutterian Brethren]. 
true Schmiedeleut. Most of the litigation took place at Group Two colonies where a minority of Group One loyalists attempted to seize or control assets under the theory that they were the true beneficiaries of the common property of the colony.

The courts in Manitoba came perilously close to having to adjudicate the competing property entitlements of the two groups. Would it be all-or-nothing, where one group of Hutterites would in effect be entitled to the property of every colony, because every colony was deemed to be entrusted to those properly affiliated with the higher Hutterite Brethren Church? And which group would that be? Would it be all-or-nothing, but only as determined by a majority vote at each individual colony as to whether the colony would affiliate with either Group One or Group Two? Or, could it be that a court would recognize both groups as within the Hutterite umbrella, properly so-called, and actually divide property on a pro rata basis between the two groups instead of using the all-or-nothing approach? If the court did that, would it be violating the internal norms of the Hutterian community that departing or excommunicated members are not entitled to a share? In part, this article examines the jurisprudence on church property entitlements in Canada to test whether there is any support for a division of assets, rather than an all-or-nothing approach.

The reason that the Manitoba courts were spared, at least for now, from allocating or dividing Hutterite property in the context of a schism, was that the defendants in the Lakeside $^{15}$ case, who later were accepted into Group Two, were in the end unwilling to counterclaim for the assets because this would violate their religious convictions against bringing lawsuits. The leaders of Group One and Group Two came to an agreement several years later: in order to stop all the litigation at other colonies, assets would be divided at these colonies on a pro rata basis. While litigation arose about the meaning and application of that agreement, ${ }^{16}$ the voluntary agreement to divide assets ended the main litigation surrounding the schism. However, the issue of how courts deal with church property in the wake of a schism is hardly an answered question, even in the Hutterite context.

Furthermore, there is also another interesting development to explore. There are quite a number of Schmiedeleut Hutterite colonies in the United States that suffered through the same schism as in Manitoba, although a clear majority there affiliated with Group Two as compared to the more even division in Manitoba. Litigation arose in the United States at several colonies and, contrary to the Canadian position, the American courts simply refused to even consider the property entitlements brought to court by Group One minorities at particular colonies. In the Poinsett ${ }^{17}$ and Tschetter $^{18}$ cases in the United States, the courts refused to take jurisdiction, even though the dispute involved the property rights of Group One and Group Two. Deciding the property rights, at least

is Hofer, supra note 4.

1. Keystone Colony of Hutterian Brethren v. James Valley Colony of Hutterian Brethren (1999), 135 Man. R. (2d) 130 (Q.B.).

Wollman v. Poinsett Hutterian Brethren, Inc., 844 F. Supp. 539 (S.D. D. Ct. 1994) [hereinafter Poinsett].

Decker v. Tschetter Hutterian Brethren, Inc., 594 N. W. 2d 357 (S.D. S. Ct. 1999) [hereinafter
Tschetter] 
in these two cases, would entangle the courts in essentially deciding a religious dispute between Hutterite factions. Such a course of action is prohibited by the First Amendment. ${ }^{19}$ This stark difference of approach between American and Canadian courts deserves examination and evaluation. How and why does the American approach to court adjudication of property disputes differ from the Canadian approach? Are the two approaches actually that far apart?

Finally, it should be noted by way of introduction that the stakes in these Hutterite cases are particularly high because of the communal property religious norms of the Hutterites. In most church property disputes, a court may declare that someone or some group can no longer control or use church property. We may well imagine that the very fact that litigation has progressed indicates that the person or group has significant psychic investment in the use of the property and has made significant financial and temporal contributions to the association through the years. However, contrast this significance with the Hutterite scenario, where the members of the religious group are prohibited from owning private property. Rather, all the land and the agricultural and manufacturing enterprises of the Hutterite colony are in effect church property owned in trust for the benefit of all, but for the individual ownership of none. The Hutterite member will usually live and work at the colony from the cradle to the grave, but unless a gift is bestowed upon voluntarily leaving or upon being excommunicated, the Hutterite is cast into the world with nothing except the skills he or she might or might not have acquired to survive on the outside. To award all the assets to Group One or Group Two in the Hutterite context is of far greater significance to the lives of the disputants than the more usual scenario of awarding sanctuaries or religious schools to one group or the other, where the losing group nevertheless still goes home to their own beds.

\section{The Judicial Resolution of Church Property Disputes in CaNADA}

Some disputes over church property may be confined to factions within a local congregation unaffiliated with any other congregation or higher mother church. Other disputes commonly take place between local congregations and the higher denominations of which they are part, or with which they are affiliated. Such disputes sometimes lead to the withdrawal of the congregation from the higher affiliation by unanimous or nearly unanimous vote at the congregational level, but more commonly they lead to a schism within the congregation between those supporting withdrawal and those who oppose it. Schisms may also take place at the higher levels of denominations and then filter right down the hierarchy to all levels of the organization.

Suppose that one side of a schism goes to court and claims that the property of the church should be entrusted to them and that the other side should be ejected from the

The First Amendment of the American Constitution provides that. "Congress shall make no law respecting an establishment of religion, or prohibiting the free exercise thereof." This provision has been made applicable to the states as well by being incorporated into the Fourteenth Amendment. See Cantwell v. Connecticut, 310 U.S. 296 (1940). 
property by the order of the court backed by state coercion, if necessary. In most cases, church property is not owned by any individual; rather it is owned by a religious association or group and held in trust for the advancement of certain purposes or for the beneficial use of the current members of the organization. The title to the property is often in the hands of a non-profit incorporated society or incorporated trustees who hold that title in trust. It is not enough to determine the legal title holder, but rather one must determine the beneficiary for whom the title is held. Which faction of the schism is the beneficiary of the trust? Is the property held in an affiliation trust for the higher denomination? Is there a doctrinal trust of some kind that confines the use of the property to certain purposes? Is there both an affiliation and a doctrinal trust? How do courts decide such cases?

\section{A. EXPRESS AND IMPLIED DOCTRINAL AND/OR AFFILIATION TRUSTS}

We may begin with the proposition that the basic approach in Canada for allocating church property when there is a schism involves the determination of the terms of the trust by which that property is held. If we know what the scope of the trust is, we can then determine which group is within that scope and is therefore the beneficiary of the trust. If one group is out of the scope of the trust, they are entirely free to leave the church, but they cannot claim any benefit of the church property, no matter how much money and labour they may have contributed to it through the years, or even if they formally hold the legal title.

But how does a court discover the terms of the trust? The first step is to discover whether there are any express trusts. The first place that a court will look to find the terms of the trust will be the written documents of the church, particularly as they relate to the time when the property in question was acquired. Are the terms of the trust expressly laid down in the title deeds, the constitution, the bylaws, or the canons of the church in question? Is there a trust that limits the use of the property for purposes of advancing a particular religious doctrine, practice, or form of ecclesiastical government? Are there provisions that govern whether changes can be made and the process for making those changes? Sometimes just the name and denominational affiliation as expressed in the foundational documents will be enough to solve the case. For example, when a congregation overwhelmingly agreed to switch from one Presbyterian denomination to another, it nevertheless lost its property because the express terms of the trust mandated the previous affiliation, even though the church operated with the new affiliation for 20 years before litigation began. ${ }^{20}$ In another case, an Ontario judge suggested that even when the person who had donated the land for purposes of the Free Church of Scotland agreed with the vast majority to switch affiliation to the Presbyterian Church of Canada, the majority could not keep the property as against even one member who remained faithful to the express terms of the original trust. ${ }^{21}$

If the terms of the trust are simply based on membership in a group as determined by majority vote, which will sometimes be the case, one can well imagine that the 
majority faction may simply excommunicate the minority faction from membership. Thus, as a matter of litigation, the property entitlement of the excommunicated faction will be linked to the judicial review of their excommunication in terms of whether the church followed its own excommunication process and whether that process conformed to the principles of natural justice. But in many cases it is quite irrelevant whether one side or the other has excommunicated members, because the terms of the trust are not based on membership by majority vote, but on conformity with some confession of faith or fidelity to a particular higher denomination. If the express trust refers to a confession of faith there may be ambiguities with which a secular court will understandably be loath to deal, in terms of the competence of the court to delve into such matters. Nonetheless, courts in Canada can enforce such express trusts.

While this article does not focus on the initial question of jurisdiction over church disputes, it should be noted that Canadian courts have not yet developed a structural autonomy of the church from the state as a requirement of the Canadian Charter of Rights and Freedoms ${ }^{22}$ similar to the American jurisprudence under the First Amendment. ${ }^{23}$ Indeed, the most prominent scholar in the area of religion and the law in Canada has repeatedly emphasized the subservience of religious organizations to the authority of the state and of the courts. ${ }^{24}$ The Charter has not changed this tradition because it is arguably irrelevant to the adjudication of most church disputes, due of the interpretation that the courts have given to s. 32, which limits the application of the Charter "to the Parliament and government of Canada" and to the "legislature and government of each province." When the courts in Canada judicially review and enforce ecclesiastical judgments, the factions of the dispute are private parties rather than governmental actors, and the courts are not considered governmental actors when they use the sword of the state to enforce the common law in favour of one side or the other. ${ }^{25}$ This is different from the American view, which holds that the enforcement

Canadian Charter of Rights and Freedoms, Part I of the Constitution ACl. 1982, being Schedule B to the Canada Act 1982 (U.K.), 1982, c. 11 [hereinafter Charter].

23. One of the seminal American articles on the value of structural autonomy for religious groups is D. Laycock, "Towards a General Theory of the Religion Clauses: The Case of Church Labour Relations and the Right to Church Autonomy" (1981) 81 Columbia L. Rev. 1373. See also C. Esbeck, "The Establishment Clause as a Structural Restraint on Governmental Power" (1998) 84 Iowa L. Rev. I; C. Weisbrod, "Emblems of Federalism" (1992) 25 U. Mich. J. L. Ref. 795; M.D. Rosen, "The Outer Limits of Community Self-Governance in Residential Associations. Municipalities, and Indian Country: A Liberal Theory" (1998) 84 Virginia L.R. 1053. I examine the lack (but need) for such autonomy in Canada in relationship to employment matters within religious groups in A. Esau, "Islands of Exclusivity: Religious Organizations and Employment Discrimination" (2000) 33 U.B.C. L. Rev. 719.

24 See M.H. Ogilvie, Religious Institutions and the Law in Canada (Scarborough: Carswell, 1996) [hereinafter Religious Institutions]; M.H. Ogilvie, "Ecclesiastical Law - Jurisdiction of Civil Courts - Status of Clergy: McCaw v. United Church of Canada" (1992) 71 Can. Bar Rev. 597; M.H. Ogilvie, "Canadian Civil Court Intervention in the Exercise of Ecclesiastical Jurisdiction" (1997) 31 Studia Canonica 49; M.H. Ogilvie, "Case Comment: Lakeside Colony of Hutterian Brethren v. Hofer" (1993) 72 Can. Bar Rev. 238.

is RWDSU v. Dolphin Delivery, [1986] 2 S.C.R. 573. In Thomas v. Norris, [1992] 2 C.N.L.R. 139 (B.C. S.C.), an action was brought for false imprisonment, assault, and battery because the plaintiff had been forcefully grabbed and initiated into the Spirit Dance without his consent. The defendants did not claim freedom of religion under the Charter, but they did claim that the spirit dance was 
of court orders in private disputes is nevertheless state action. ${ }^{26}$ So in Canada, in theory at least, the courts could untangle the mysteries of doctrinal religious trusts and declare that one group was heretical.

The potential for court enforcement of express trusts may be illustrated from our Hutterite example. Even if the Articles of Association of Lakeside Hutterite Colony (similar to the Articles at other colonies) allow for excommunication from membership by majority vote, there is a prior express trust, which includes the following qualifications: the purpose of the colony is to "worship God according to the religious belief of the Hutterian Brethren Church"; ${ }^{27}$ a person must "become a member and communicant of the Hutterian Brethren Church"; ${ }^{28}$ no member can vote at a meeting unless "He conforms to the practices and regulations laid down from time to time by the Schmieden-Leut Group of Hutterian Brethren";29 property of the colony can only be managed by a Board of Directors who must, at all times, "be members in good standing of the Hutterian Brethren Church"; ${ }^{30}$ the Articles of Association cannot be repealed or amended unless such change is in "accordance with the beliefs of the Hutterian Brethren Church"; ${ }^{31}$ any member "who shall cease to be a member of the Hutterian Brethren Church shall leave the Colony"; ${ }^{32}$ the colony cannot be dissolved without the consent of the Schmieden-Leut Group of the Hutterian Brethren Church; and finally, any property of the colony upon dissolution remains vested in the Hutterian Brethren Church..$^{33}$ All of these references to polity and purpose beyond mere majority votes are multiplied when one looks at the higher Constitution of the Hutterian Brethren Church, which the Lakeside Colony signed and affirmed. Just to mention one item, both the Constitution of 1950 and the new Constitution of 1993 import the confession of Peter Riedemann ${ }^{34}$ as a doctrinal statement of faith for the church. ${ }^{35}$ However, the Constitution can be amended by the Board of Managers of the constituted transnational church. ${ }^{36}$ It seems obvious that whether the Hutterite polity is congregational or hierarchical, there are nevertheless clear express requirements of affiliation and doctrinal conformity with a larger group that transcends the particular colony. Thus the courts may yet face the unpleasant task of giving content to the scope of this trust to determine whether Group One or Group Two, or both, are within it.

an existing Aboriginal right. The court held that the Charter did not apply to possible defenses to the tort claims between private individuals.

New York Times v. Sullivan, 376 U.S. 254 (1963).

"Articles of Association, Lakeside Colony," clause 2 [on file with the author].

Ibid. clause 3.

Ibid., clause 12.

Ibid., clause 13.

Ibid., clause 44.

Ibid.. clause 39 .

Ibid., clauses 36 and 37.

Peter Riedemann wrote a confession of faith while in jail in 1540 and to this day his work has nearly the authority of scripture for Hutterites. A recent translation by John J. Friesen is Peter Riedemann's Hutterite Confession of Faith (Waterloo: Herald Press, 1999).

"Preamble," Constitution of the Hutterian Brethren, supra note 14. New and old versions are the same.

Ibid. clause 49 in both new and old versions. 
I am suggesting that Canadian courts will attempt to interpret these religious doctrinal trusts if they need to, while many courts in America, as I shall argue in the next part of this article, will refuse to do so, even when these trusts are express. To avoid the problem of secular courts judging religious issues, some American courts either defer to the decisions of the ecclesiastical authorities as to whether the express doctrinal trust has been broken, or defer to the majority opinion at the congregational level, or simply declare such religious creedal formulations as unenforceable as a matter of the secular determination of property rights.

But of far greater importance in understanding the difference between American and Canadian jurisprudence is the argument that, if the Canadian courts cannot find an express affiliation or doctrinal trust in the documents of the church, the court will have to imply the terms of the trust. This approach has long been rejected in America. If express doctrinal trusts are problematic for the courts, the difficulties are multiplied twenty-fold with implied doctrinal trusts. When no express trust existed, the English courts adopted an implied original doctrinal trust concept that basically implied the following as the terms of the trust: given the absence of an express trust to the contrary, the church property is held in trust for the group which remains most faithful to the original doctrine and polity that the church had at the time the property was acquired. ${ }^{37}$ Professor Ogilvie has expressed the concept in the following way:

It is a well settled principle of law that the property of a religious institution must be held and applied to the original purposes for which that institution was founded, that is, for the original "trust". Such property cannot be re-directed to other purposes by a mere majority of members and where a majority decides upon a diversion, the property remains in trust for the dissenting minority (even one person) who adheres to the original trust for which the property was given. ${ }^{38}$

One might argue that we should only imply the terms of a trust when there is no express trust whatsoever. But historically the courts might imply a more detailed trust based on the more general words of the express trust. For example, the express terms of a property deed in 1810 said "for the use of Christ Church." ${ }^{39}$ There was nothing more in terms of a specific confession, a statement as to denominational affiliation, or a first constitution setting out a process of governing or amending the internal law of the church. In fact, when the church was established it was intended to be, and became, an Anglican Church. When one of the members brought an action alleging that the current priest was violating the doctrines (including worship modes) that existed at the time of the founding, the court implied that the property was stamped with a trust to follow the original doctrine and modes of worship of the Anglican Church at the time the land was deeded to the parish. Recognizing that this in effect paralyzed a church from changing, Palmer J. nevertheless affirmed that unless the foundational documents 3 E.R. 601 and (1820), 4 E.R. 435 [hereinafter Craigdallie].

$3 \mathbf{n}$ Religious Institutions. supra note 24 at 209-10. The leading commentary on this topic in Canada is M.H. Ogilvie, "Church Property Disputes: Some Organizing Principles" (1992) 42 U.T.L.J. 377 [hereinafter "Church Property Disputes"].

31) Bliss v. Christ Church. [1887] Tru. 314 (N.B. S.C.). 
allow a material change, property cannot be diverted away from the purposes for which it was received.

\section{B. CRITICISM OF IMPLIED ORIGINALIST Doctrinal. Trusts}

If the traditional approach of implying an original doctrinal trust is still in fact the state of our law, one might well argue that the courts should no longer adopt it. While such an argument could be based on the idea that we should have more jurisdictional autonomy of ecclesiastical authorities and on arguments of judicial incompetence to deal with religion, I would simply question the policy behind the principle that we should imply an original doctrinal trust.

When there are no express terms of trust, or the terms are thought insufficient, why should our law imply that it is the original doctrine and polity or affiliation that counts? If we assume that we are simply enforcing the charitable purposes of the original donors or purchasers we are faced with the reality that many people have often given far more to the upkeep of the church over the years than the persons who may have helped purchase the land or founded the congregation. The implied original trust may kick people out of a church that they have supported for thirty years because a court determines that their faith is sufficiently different from some persons who have been dead for a century. However, the basic weakness with the implied original doctrinal trust concept is the assumption that, beyond the express words of any deed, we should imply that those who purchase the property for a church, or donate to it or give foundation to it, actually intend such a frozen doctrinal trust as opposed to what might be called an organic trust.

Suppose that I give something in trust for John Doe. Forty years from now John Doe may be a very different person than he is now, but at the same time he is still John Doe. People fundamentally change, but at the same time fundamentally are still the same person. In the context of church congregations we are of course not dealing with one person or even the lifetime of one person, but is the analogy to personhood completely inappropriate? I do not think so. People who are members of a religious group, particularly groups that have a totalistic religious world view, experience themselves as a people, as a community, as a distinct group. It is not unrealistic to assume that when my grandfather gave a corner of his land in trust for the Mennonite Brethren congregation of Vauxhall, Alberta, he was making a donation to a people, with a history, with a narrative that bound them together, and that his gift did not imply a frozen doctrinal trust, even if he might be horrified at some of the beliefs or practices of the congregation if he came back from the grave today. His horror would undoubtedly subside when he compared the conservatism of that congregation against others'. But in any event, that does not change my point.

This is not to say that it would always be wrong to imply a doctrinal trust. I might indeed intend to give something in trust for Jane Doe so long as she practices law, or remains a member of the Liberal Party, or does not take drugs, etc. Ignoring the legalities of such conditions for purposes of illustration, we might well attach conditions and expectations to our gift. My grandfather might have intended that the 
church should not depart from a particular Anabaptist brand of the faith. But why do we always make an assumption that, absent an express trust we have a fixed, originalist, doctrinal trust rather than a flexible, growing and changing, organic trust?

One might object to the concept of adopting an implied organic trust concept because it does not provide any genetic test but for majority vote to solve a dispute when in a subsequent schism one group says that they are the real John Doe and another group says they are the real John Doe. My point, however, is that we could adopt an implied organic trust and reverse the current presumptions. Under the implied doctrinal trust, the presumption is that one cannot depart from fundamental doctrine unless the trust expressly makes provisions for change and those provisions are followed. Under an implied organic trust, however, the presumption would be that one can make changes to doctrine or affiliation (by majority action in the absence of provisions to the contrary), unless the trust expressly provides that some or all doctrines or affiliations are unalterable. Why has the common law adopted one set of presumptions over another set that could just as well be adopted? Is it because religion is primarily viewed as a belief system rather than as a holistic and communitarian way of life?

If we switch to an implied organic trust we could also switch presumptions in regard to property entitlements. At the moment, the presumption is that in the event of a schism, the property goes to one group or the other, all or nothing, on the basis of which group is in or out of the scope of the original doctrinal trust, absent express provisions to the contrary. With an implied organic trust, one might also have an all-ornothing rule where usually the majority would win. But why could we not adopt the presumption that property will be divided pro rata in the event of a schism absent express provisions to the contrary? I admit that such a presumption is not free from the need for further elaboration. What is a schism as opposed to a legitimate excommunication? What is a schism within the church and what is a switch of religions as in Hofer v. Hofer? $?^{40}$ These problems certainly deflate the appeal of any division presumption, but as we will see, they are no less problematic than the difficulties we have with implied doctrinal trusts.

\section{Canadian Decisions on Finding and Enforcing EXPRESS AND IMPLIED TRUSTS}

When we examine the Canadian cases, we confront strands of jurisprudence that cast doubt on the proposition that finding and enforcing express or implied doctrinal trusts is as well-settled in our law as has been suggested. ${ }^{41}$ The performance of Canadian courts may even cast doubt on the proposition that the American position and the Canadian position are so radically different. While Canadian courts certainly have found and enforced express and, very occasionally, implied doctrinal and affiliation trusts, the courts have retreated from interpretations that would exclude people from the scope of a trust except in the most plain and obvious circumstances.

1 See "Church Property Disputes," supra note 38. 
We start with the Quaker schisms in the late nineteenth century where we already see a Canadian flirtation with an organic affiliation trust rather than the adoption of a strict doctrinal trust approach. At the New York Yearly Meeting of Friends, a revised Discipline was passed in 1877 replacing the Discipline of 1859. Various local Quaker groups throughout North America split into competing camps between the so-called Progressives who supported the new Discipline and the Traditionalists who did not. Such a schism happened at the West Lake Monthly Meeting of Friends in Ontario where a small minority of Traditionalists fought for control of the property with the larger group of Progressives who, through the trustees, controlled the keys to the building. There were various violent incidents, and eventually the Progressives commenced court action to restrain the Traditionalists from occupying the property. However, the trial judge turned the property over to the small minority of Traditionalists. ${ }^{42}$ The land deed in 1821 simply stated "for the benefit of West Lake Monthly Meeting." Justice Proudfoot, applying the foundational English case of Craigdaillie v. Aikman, ${ }^{43}$ implied an original doctrinal trust that the property was to be entrusted to that group who adhered to the fundamental doctrines and practices of the Quakers as existing in 1821 . Comparing in details the Discipline of 1859 , which he claimed was a retroactive capture of the 1821 situation, with the new Discipline of 1877 , Proudfoot J. concluded that the departures were clear and fundamental and thus the property was handed over to the small minority Traditionalist party. But the Progressive majority appealed to the Ontario Court of Appeal and won. ${ }^{44}$

At one level, the appeal decision might be seen as simply an application of the implied doctrinal trust, but illustrating the difficulties of identifying both the original scope of such a trust and the difficulties of determining whether the current faction in question was in or out of the scope. The Progressives could argue that the scope of the doctrinal trust was much wider and more flexible than the Traditionalists asserted. Quakers were known to have new insights, tended not to be creedal, and changes had been made continuously throughout several hundred years of their history as a religious group. Indeed, the Discipline of 1859 , which the defendants were using as the basis for identifying the doctrinal trust of 1821 , contained provisions that were not in existence in 1821 .

We see here the problems that courts face in trying to identify the scope to give to an implied, or even an express, doctrinal trust. There is a difference between including the doctrine of pacifism as obviously in the Hutterite category and the more ambiguous idea that men must have suspenders rather than a belt to hold up their pants. The exercise of implying doctrinal religious trusts at a point in time is not a simple exercise of fact-finding, but a subjective exercise of circle-drawing that depends in part on the length of the judge's arm. Who is to say what is absolutely fundamental and what is less so and therefore changeable? In addition, we see the problem of establishing subsequent departure. If the group adds something new as opposed to removing

s4 Dorland v. Jones (1885), 12 O.A.R. 543 (C.A.). 
something, is that a departure? If the group expresses something in a different way? What is a material departure as opposed to a trivial one?

Essentially on the implied doctrinal trust level, the Ontario Court of Appeal reversed the onus used by the trial court. The trial court had said it was up to the Progressives to prove that they had not breached the doctrinal trust. The Court of Appeal, however, stated that the Traditionalists had to prove the content of the original trust and the materiality of departure, and that they had not proven that the Progressives were outside of the doctrinal scope of Quakerism as existing in 1821. That the Court was quite unwilling to imply a rigid and detailed doctrinal trust is indicated by the heavy burden placed on those who alleged that there had been a departure. Chief Justice Hagarty, quoting American authority, asserted that the departure had to be "so deep and radical as to destroy its identity." Although it was "as painful as it is unusual to be obliged to speak judicially on such a subject, ${ }^{, 46}$ Hagarty C.J. did his own comparison of the new and old Disciplines and observed that much of it involved "metaphysical distinctions and subtleties, which are beyond my mental powers to distinguish, much less to determine." $\$$ Nevertheless, he concluded,

I see nothing in the evidence before us, to warrant the conclusion that any substantial or fundamental variance, has been proved against the plaintiffs, from the leading doctrines and principles of the Society of Friends. ${ }^{48}$

While the other judges came to the same conclusion, on the level of the implied original doctrinal trust concept there was an additional strand suggested, namely that the very doctrinal trust of this particular religious group included the principle that doctrine could be changed in the light of new revelations. The authority of Scripture could not change, but understandings of it might. Rather than having an implied doctrinal trust with no express process of change, this case involved a doctrinal trust with change built right in.

There is another level to the case which closely resembles the American politydeference approach, to which I will turn in a moment, and perhaps flirts with the concept of an organic affiliation trust, as I call it. Both Burton and Patterson JJ. took the approach that a doctrinal trust was not what this case was about. When we talk about implying the original trust, we could include polity as well as doctrine or even place the emphasis on polity and not doctrine. There may be no express trust that a church is to be affiliated with some denominational conference, for example, but in fact an examination of the founding circumstances may well lead a court to conclude that such was part of the original trust. What counted was that in 1821 the property was not given to a stand-alone Quaker congregation, but was given to a congregation that was part of a larger and well-defined ecclesiastical denomination. At that time, the larger polity had various levels of authority and various appeal processes for discipline in 
terms of doctrine and practice, as well as authority at the highest level to deal with doctrinal matters. The plaintiffs clearly fell within that affiliation and organized structure, while the defendants were not and had formed their own separate structure.

A court could conceivably determine that an express or implied affiliation trust existed without any added implied doctrinal trust. That is, we might give property to John Doe so long as he is married to Jane Doe. It may turn out that Jane Doe becomes false and John Doe leaves Jane and takes up with Sally. The affiliation trust has been broken by John Doe irrespective of what the cause for the break might be. Thus, the affiliation trust without an implied doctrinal trust might lead a court to hold that the local congregation, even if it has title in local trustees, is held in trust to a relationship with a higher or broader ecclesiastical body, irrespective of how the higher body behaves. If everybody at the local level pulls out of the affiliation, the property can still be taken over by someone willing to hold it in trust for the higher church. This is a relational organic trust, not a doctrinal one. As stated by Burton J., "If this view be correct it must necessarily be of no importance, whether the doctrines and practices of the members of the Meeting as practiced by the plaintiffs be regular and orthodox or the reverse." ${ }^{49}$

There may of course be situations of schisms at the highest levels where there is as much trouble identifying which competing authority is the real Jane Doe, as there is at the local congregational level in terms of which party is John Doe. Furthermore, it would seem that in theory the original implied trust concept in our law might imply a doctrinal trust on top of an affiliation trust. In the absence of an express trust to change doctrine, if a local church is originally affiliated with a Lutheran Synod, for example, and that Lutheran Synod departs from the doctrine that it had at the time the local affiliation took place, absent express provisions allowing for change, the faction that disagrees with affiliation might not lose the rights to the local property. Thus we might give to John Doe as long as he is married to Jane Doe but with the condition that, should Jane Doe abandon her vows, the property will vest in John absolutely.

But in the Quaker case it would appear that the Court of Appeal primarily focused on the affiliation trust per se rather than any added doctrinal trust on the higher authority. The judges were willing to defer to the higher ecclesiastical authorities who claimed that the Progressives were the successor polity of the local, national, and international organizations of the church, and that it was the minority who had seceded from the body. Much of the discussion might support a kind of implied organic affiliation trust, in that the court was looking for a live body - an active successor organization - and not looking at conformity to an abstract frozen set of beliefs in finding the beneficiary of the trust. The Traditionalists appealed to the Supreme Court of Canada, which upheld the decision of the Ontario Court of Appeal without substantially adding anything to it, and leaving the competing strands of justification in place. $^{50}$ 
These tensions played out again following a schism at the highest level of the United Brethren in Christ Church at a General Conference in Pennsylvania in 1889. A new constitution and confession was adopted, but 15 delegates, including one of the six bishops, walked out and said that the remaining 110 delegates had withdrawn from the true church. When reconciliation failed, the 110 delegates claimed that the 15 had left the true church. The group of fifteen then formed their own ecclesiastical structure but claimed to be the true United Brethren in Christ. Divisions at the higher level between the factions eventually lead to divisions within some of the local congregations. One such division, at the local church in Port Elgin, Ontario, led to litigation. ${ }^{51}$

The trustees of the local church - and one may assume a large number of the congregation, albeit a minority - sided with the 15 who objected to change and refused to acknowledge the authority of the minister or bishop in the affiliation ladder. New trustees were appointed by the majority group loyal to the 110 and they brought action to gain control of the church property. The local property was simply deeded to the Church of the United Brethren in Christ. Which group was the successor to the original congregation and entitled to the property? Which group was the seceder and not entitled to the control of the property because they had left the church? Just as in the Quaker case, the lower court used the implied original doctrinal trust concept and held that the minority group of 15 were the successors because they had stuck with the original confession, but as in the Quaker case, this holding was reversed by the Ontario Court of Appeal. ${ }^{52}$ Again there were two strands to the decision.

One strand was the argument that the Constitution of the Mother Church allowed changes to be made by a ratification vote of two-thirds of the whole church and that, subsequent to the Conference of 1889 , the changes were approved by a vote of around 51,000 in favour, with 3,000 opposed. Confined to this strand, this case has nothing to do with the interpretation and application of any implied trust, whether organic or doctrinal. There was express provision for change, and the issue involved the regularity of the vote and the reach of that permissible constitutional change.

However, because of doubts as to the regularity and reach of the change, the second strand of the case dealt with the issue of departure from an implied original affiliation and doctrinal trust. In this regard the plaintiffs, as in the Quaker case, argued that the various changes were not so essential as to change the identity of the group. They did not adopt a new religion or abandon a religion. Furthermore, the church was about one hundred years old and had made various changes through the years without losing its identity. In addition, the original founders of the church were divided on certain doctrinal matters. Finally, the plaintiffs made the last-resort argument that might be made in every case: We are a people. We are an organic community. We have a confession that is no different from a dozen other evangelical groups. The confession does not define our identity as the majority successor group to the founding organic community. ${ }^{53}$ On the other hand, the defendants replied that when the local church 
was founded there was a particular doctrinal constitution and confession of the church, and the church should be held in trust for the group that followed that original confession. The defendants also argued that the changes to the confession were vitally important and contained fundamental matters and that the court should be careful not to second-guess the opinion of the defendants as to the importance of the changes, as it had done in the Quaker appeal. ${ }^{54}$

The judges of the Court of Appeal, however, once again compared the old confession to the new confession and considered the materiality of changing "ordinances" to "sacraments" and "the resurrection of the body" to "the resurrection of the dead." Chief Justice Hagarty concluded that under the implied original doctrine trust concept, one could not depart from fundamental doctrines, but the burden of proof was on the party claiming that fundamental doctrines had been violated, and the evidence must show a clear and substantial departure so that a court can say, in effect, that "we have a different denomination." Applied to this case, Hagarty C.J., with other justices concurring, found that the changes were not material. This was not an attempt to change fundamental doctrine, but rather an attempt to express the doctrines in a better way. At least one of the judges, Maclennan J., again flirted with the idea of an organic affiliation trust rather than a doctrinal one. In any event, the church property was awarded to the Progressive group who supported the new constitution and confession, and the Traditionalists either had to conform or start their own church. This decision served as a precedent for conflicts at many of the other Brethren in Christ churches in Ontario. $^{56}$

Thus we do have historical precedent in Canada for implied originalist doctrinal trusts, but the courts have been loath to draw the circle of their scope to exclude anyone unless the evidence of departure is clear and fundamental. On the issue of defining the scope of a doctrinal trust, whether implied or express, and the materiality of the departure from original doctrine, some cases are easier than others.

In 1894 a group of Icelanders in Winnipeg formed an Icelandic Evangelical Lutheran Church, and in the founding constitution it was expressly stated that "This congregation accepts the doctrines of the Sacred Scriptures in the same manner as the Lutheran Church of Iceland by its confession." ${ }^{57}$ In 1919, this congregation received a request from an Icelandic Unitarian congregation seeking to merge the Lutheran and the Unitarian congregations. Several meetings were held in which a majority of the members refused to agree to the merger, but finally, at a special meeting, the regularity of which can be doubted, the merger was approved by a vote of 38 to 16 . The antimerger group elected new trustees and sued. It was not difficult for the trial court to establish that various Lutheran beliefs, like the Trinity of the Godhead and the Divinity of Jesus, were fundamentally different from the Unitarian belief, and that those who accepted union with the Unitarians had breached the doctrinal trust. The judge ordered

Ibid. at 269-71.

Ibid. at 261.

See. e.g., Brewster v. Hendershot (1900), 27 O.A.R. 232 (C.A.).

Anderson v. Gislason (1920), 30 M.R. 536 at 537 (C.A.). 
that the title and the keys to the church be handed over to the anti-merger party. This was upheld by the Court of Appeal. ${ }^{58}$ We may also include the Manitoba Hutterite case of Hofer v. Hofer ${ }^{59}$ in this line of cases where the departure from one religion to another is obvious. Both of these Manitoba cases involve to a significant degree the interpretation of express doctrinal trusts, rather than any implied trusts.

Most cases, however, do not involve such a sea-change of doctrine, and thus it is more difficult for the court to determine the matter - whether express or implied. Despite the rhetoric that the church property should go to the party that sticks closest to the original doctrinal identity of the founding congregation - absent express provisions allowing for doctrinal change to be made - courts are loath to award property to minority parties. There is a kind of deference to the majority, even though defining the scope of the doctrinal trust and judging the materiality of change puts the courts in a position of second-guessing the minority party that insists that the change is fundamental to it. On the other hand, accepting every plea of departure is unfair to the majority claim that they are still John Doe, as it were.

Despite the numerous references to the implied original doctrinal trust, one finds that historically in Canada many of the cases were determined not on implied original doctrine, but rather on implied original affiliation trusts. While such cases do not necessarily provide support for an organic approach, they certainly reduce the number of precedents providing support for an implied doctrinal trust approach. There are cases where the courts have had to decide whether a particular affiliation with one branch of the mother church or another - or none at all - was part of the original trust and was unchangeable. One such case, arising out of a parish in Alberta, was litigated for fifteen days at trial and then went through all the levels of appeal to end up at the Judicial Committee of the Privy Council in London in $1908 .^{60}$ In this case, there was no express trust on affiliation, so the courts had to decide whether there was an implied trust that the church was affiliated with the Greek Orthodox Church (not under Roman Papal authority) or with the Greek Catholic Church (under Papal authority), and award the church property in trust to one group or another. The Orthodox, rather than the Catholic, ultimately won. This is in contrast to a case in Manitoba involving the same sort of affiliation issues in which a court suggested that the Catholic faction should win. ${ }^{61}$ One may question whether the politics of the judges - particularly in regard to pro- or anti-Catholic bias - had as much to do with the determination of the trusts, as did the actual conflicting evidence as to what the original purpose of the congregations were in terms of the affiliation issue.

On the issue of implied affiliation trusts, a number of Lutheran cases were decided in different provinces at around the same period. In an Ontario case, it was held that a Lutheran congregation had been established independently from affiliation with any higher Lutheran Synod, and that a few members who broke away to join the Missouri 
Synod had no claim to control the assets of the congregation. ${ }^{62}$ On the other hand, a Saskatchewan judge determined that a Lutheran congregation in Neudorf had been founded as a congregation affiliated with the Missouri Synod, and he therefore ruled that all the church property be held in trust for the five members who had not voted to change affiliation to the Ohio Synod. ${ }^{63}$ Even though an Ontario judge found no doctrinal issues to be at stake, the property of a Lutheran congregation established as part of the Synod of Canada was given to that part of the congregation, however big or small, that retained affiliation with that denomination, rather than the group who voted to join the Missouri Synod. ${ }^{64}$

Similarly, in 1909, a congregation of Lutherans affiliated with the Missouri Synod established a church in Alberta. The confession of faith was a common Lutheran confession with no express affiliation with a particular branch of Lutheranism mentioned in the trust deed or founding constitution. However, in a subsequent document of incorporation, the specific affiliation with the Missouri branch was de facto stated. Eventually a majority of the church voted 35 to 7 to switch affiliation from the Missouri Synod to the Manitoba Synod. The minority sued and Walsh J. awarded all of the property to the minority. ${ }^{65}$ The majority group argued that the scope of the trust was the Lutheran confession, but the minority group claimed that the scope of the trust was narrower and included the affiliation with the Missouri Synod. Justice Walsh was satisfied that this affiliation was indeed of critical and fundamental importance to the original founders, that the constitution itself said no fundamental matters could be changed without unanimous consent, and therefore the minority was entitled to the property.

The question of an implied affiliation trust also arose in Manitoba where the issue actually involved an alleged express trust term against affiliation. The case involved an independent Greek Orthodox congregation, which had originally been formed by seceding from a Greek Orthodox congregation affiliated with the Russian Orthodox church as the mother church. The seceding congregation stated in the founding constitution that "The parish shall not owe its subordination either to the Russian Orthodox and its officials, or the Pope of Rome or his deputies." changes were proposed to the constitution including substituting the following section in place of the previous: "The doctrine and ceremonies taught and administered in the Church are to be those of the Greek Orthodox Church." ${ }^{67}$ The changes were passed by a vote of 24 to 15 and the minority went to court. In ruling for the minority and granting them control over the property of the church, the trial judge stated that the constitution did not provide for changes to fundamental polity or doctrine and that the independence clause was fundamental. On appeal, the defendant majority claimed that the constitutional changes were not meant to change the independent polity of the

Huegli v. Pauli (1912), 4 D.L.R. 319 (Ont. H.C.).

Siein v. Hauser (1913), 15 D.L.R. 223 (Sask. S.C.).

Forler v. Brenner. [1922] Ont. W. N. 249.

Henning v. Trautman. [1926] 2 D.L.R. 280 (Alta. S.C.).

Brendzij v. Hajdij, [1926] 2 D.L.R. 626 (Man. Q.B.) at 627.

Ibid. at 627-28. 
church. The Court of Appeal declared the new clause of the constitution null, but nevertheless overturned the lower court's decision that awarded the church property to the minority. The court also noted that no steps were taken to affiliate this church with any higher authority. Rather, until some active steps were taken by some faction to actually affiliate against the independence polity, both groups were still members of the church and within the scope of the trust.

Notice that to this point in time we do have cases where a minority might get the property on the basis of an implied original trust. However, these cases are not about implied doctrinal trusts where the courts examine substantive changes to religious views either at the local level or at the higher levels of the denomination against implied originalist doctrinal confessions. Rather, the cases are about implied affiliation trusts.

More relevant to the issue of whether Canadian courts will actually imply a doctrinal trust is a 1929 Baptist case, where again we see the unwillingness of the Ontario Court of Appeal to oust a faction from the church on the basis of doctrinal departure. To a significant degree this is actually a case dealing with an express doctrinal trust rather than an implied one. When a Baptist congregation was founded in Hamilton, the trust deed expressly included a lengthy confession of faith, although no specific affiliation with a particular Baptist denomination was mentioned. Years later, a dispute took place when the pastor and the majority decided that the congregation should disaffiliate from one Baptist denomination and join another Baptist denomination. The new denomination had a confession of faith and the majority now required that as a condition of continuing membership, everyone had to sign this new confession of faith. The minority opposed to the new affiliation refused and eventually were declared to have been excommunicated from membership. The minority took the case to court and the trial judge concluded, after listening to the theological experts debate each other, that the new confession departed substantially from the confession found in the express trust deed. Since there was no indication in the original deed that the confession could be changed by majority vote, the majority had breached the trust in signing the new confession and its decision to expel the minority was declared void. ${ }^{68}$

The majority appealed to the Ontario Court of Appeal, where Riddell J.A. upheld to some degree the trial decision that the minority could not be expelled. He then added a twist directing that the minority could not expel the majority either. ${ }^{69} \mathrm{He}$ asserted that under the express terms of the trust the majority was not prohibited from affiliating with another denomination. However, in doing so, they had no authority to require the minority to sign any additional statement of faith as a condition of membership that went beyond the express confession of faith in the original trust. The plaintiff minority could not be expelled by the defendants for failing to sign. In addition, Riddell J.A. suggested that this did not necessarily mean that the church property should be handed 
over to the exclusive use of the minority group. His reasoning on this issue was so confusing that he was compelled to issue another judgment. ${ }^{70}$

In the second judgment, Riddell J.A. suggested that the new confession did not, as the trial judge had concluded, contradict the old confession, rather it was consistent with it. The new confession simply expressed the same doctrines by way of clarification and added several statements on other doctrines not found in the original confession, but not inconsistent with those found there. New doctrines could be added so long as they did not contradict the existing ones. In essence, Riddell J.A. concluded that both groups were within the original trust. Those who signed the new confession had not breached the trust because they believed in the old confession plus additions, while those who refused to sign had not breached the trust in limiting themselves to the original confession. The plaintiff minority had succeeded in retaining membership, but not in kicking the majority off the property. The problem for the majority of course was that the court affirmed that additional doctrines could be adopted, but that the church, due to the express original doctrinal trust, could not force any minority to accept the additional doctrines by way of making such acceptance a condition of membership.

This case again illustrates the problem of reconciling change and having a property concept based on fixed doctrinal boundaries and the unwillingness of courts to apply, with any sort of rigor, the so-called originalist doctrinal trust, even when express. This unwillingness conflicts with the fact that the implied original doctrinal trust was reinforced by the House of Lords in the famous Overtoun decision. "In that case, judges produced hundreds of pages debating such doctrines as absolute double predestination, and a majority of the court awarded all of the Free Church of Scotland properties - including some 800 churches, three universities, and huge endowments - to a tiny minority of the church, because the court decided that the majority had departed from the original doctrinal trust. Legislation was passed to overturn this decision and to allow for the equitable division of the property between the two groups.

The fact that the legislation was used to avoid the common law doctrine may be evidence itself of its unsatisfactory nature. When various Presbyterian denominations in Canada decided to merge in 1874, legislation was passed to reverse the possible consequences of both express and implied trusts in the eventuality that such a merger might be a violation of the original doctrinal or affiliation trusts of various congregations. ${ }^{72}$ Instead, each congregation had six months to decide by majority vote to agree to the union or pull out of it. Subsequent disputes over the constitutionality and effect of the legislation led to litigation. ${ }^{73}$ Similarly, in 1925, the United Church of Canada was created by the union of the Methodist, Congregational, and Presbyterian churches. ${ }^{74}$ But the decision of the General Assembly of the Presbyterian Church was

7" Wodell v. Potter, [1930] 2 D.L.R. 449 (Ont. C.A.).

" General Assembly of Free Church of Scotland v. Lord Overtoun, [1904] A.C. 515 (H.L.).

$\because \quad$ Presbyterian Union Act of 1874,38 Vict., c. 75 (Ontario).

"Sec, e.g., McPherson v. McKay (1880), 4 O.A.R. 501 (C.A.), affirming (1878), 20 Gr. 141 (H.C.).

is For an overview of property disputes in this regard see Religious Institutions, supra note 24 at 212-15. 
that local congregations could decide for themselves if they wanted to join the union or not. Given the bitter disputes over the issue of union, it would be entirely predictable that those groups who opposed union and who lost the vote at their own congregational levels would then go to court and argue that the congregation would be in breach of trust, either express or implied, if it joined the union, and that the property should remain in the hands of the "true" Presbyterians, even if in the minority.

To facilitate the creation of the United Church, special federal legislation was passed and duplicated by provincial legislation to, in effect, abolish the implied original trust doctrine and substitute a contemporary majority vote of members for or against union. $^{75}$ Various rules were imposed in the legislation with respect to voting procedures, and jurisdiction was given to special tribunals to facilitate property transfers and to deal with disputes. Still, in the end, there was a considerable amount of litigation across Canada over the constitutionality of the legislation, over voting procedures and over interpretation. ${ }^{76}$ We need not deal with these issues other than to note the litigiousness of the factions.

Getting back to the application of implied doctrinal trusts as the basis for settling property disputes in a schism, the more recent cases have not illustrated renewed enthusiasm for the concept. In the last two decades, there are indications that Canadian courts are moving away from implying more detailed formulations of doctrine or governance if such formulations are not expressly included in the foundational deeds or constitution of the church to begin with. The courts have also refused to go beyond the general words of the express trust, which simply identify a religion and are often wide enough to encompass both factions. While there has been no explicit overruling of the implied originalist doctrinal trust, there does not appear to be much Canadian application of it.

For example, in a 1983 Ontario case, albeit on a preliminary injunction application, the court refused to find that the rabbi and majority of the congregation, who had agreed to allow mixed seating and to allow women to take part in the service, had thereby breached the religious trust that the congregation was supposed to be of the Orthodox Jewish faith. ${ }^{77}$ No written constitution or bylaws of the congregation directed the property to be used in a particular way, so the application was dismissed. If the case had gone to trial there may well have been a determination as to whether an implied trust existed and what the content of that trust was, but certainly the judge on the preliminary motion was not interested in getting into such issues. In a statement that might have come out of an American rather than Canadian court, Callaghan J. held as follows:

7. See. e.g. Stover v. Drysdale. [1925] 4 D.L.R. 994 (B.C. S.C); Osborne v. Milliken (1925). 28 O.W.N. 40 (H.C.): The Wick Case, [1926] 1 D.L.R. 829 (Ont. Prop. Comm.); Ballantyne v. (raig (1926). O.W.N. 411 (Div. C.); Richmond Hill Presbyterian Church: Maple Valley: Conn, [1926] 4 D.L.R. 365, 378. 385 (Ont. Orde J.); Aird v. Johnson. [1929] 4 D.L.R. 664 (Ont. C.A.): Ferguson v. McLean. [1930] S.C.R. 630; United Church of Canada v. Presbyterian Church of Canada, [1935] I S.C.R. 708. 
While I recognize that the courts have a role to play when congregations become dissentient among themselves in relation to property, contracts, or other civil rights, 1 am of the view that in the circumstances as presented in this case, the issue is fundamentally an ecclesiastical issue which must be resolved outside the courts of law. The functions of a court of law exclude the consideration of such issues. Accordingly, the application will be dismissed. ${ }^{78}$

In a 1981 British Columbia case, a small faction of a congregation claimed all the property of the church because the minister and majority group were breaching an implied trust that required baptism in this church to be a sacrament of sprinkling and not a symbolic believer's baptism by immersion, as taught and practiced by the majority. ${ }^{79}$ After hearing all the testimony of competing theological experts on the subject and examining the constitution and bylaws, the judge found no express trust on modes of baptism and rejected the claim. There was no express trust requiring sprinkling and insufficient evidence existed as to any implied trust of fundamental doctrine that only sprinkling was a valid form of baptism. The minority group appealed to the Court of Appeal, who overturned the decision and sent it back for a new trial on the basis that the real dispute was not about sprinkling versus immersion, but about infant versus adult baptism. ${ }^{80}$ At the new trial, the battle of theological experts was renewed, and another trial judge refused to find that infant baptism to the exclusion of adult baptism by immersion was mandated by the trust, even though there was evidence that sprinkling had been used and that babies had been baptized for many years subsequent to the founding of the church. ${ }^{81}$

Notice the reluctance of courts to imply a doctrinal trust beyond whatever express trust exists, however cryptic. If this is the case, can we still find support for an implied doctrinal trust when no express trust exists whatsoever? The court focused more on the lack of a written founding confession to conclude that both infant and adult baptism were within the scope of the original trust. The majority could not be prevented from using the property because of their practice of adult baptism and, given that the majority accommodated the minority by allowing infant baptism by outside ministers, the minority would have to concede or leave. Having lost in the courts, some members of the minority group, and particularly one lay leader of the group, began to disturb services, picket the congregation, and bother the majority to the point that this leader was expelled from membership. The majority faction ultimately applied to the courts for an injunction to restrain this ex-member from entering the church and picketing on the premises. ${ }^{82}$ Once again the dissenting minority failed to control the property on a theory that the majority had committed doctrinal heresy, in contrast to those cases where minorities have succeeded when the majority has committed affiliation heresy.

Ibid. at para. 11.

Chong v. Lee (1981), 29 B.C.L.R. 13 (S.C.).

The decision of the B.C.C.A. appears to be unreported, although there is a report of an unsuccessful application brought by the plaintiff minority to try to stop the majority from making constitutional changes pending the appeal. See Chong v. Lee, [1981] B.C.J. No. 1106 (C.A.), online: QL (CJ).

Chong v. Lee, [1983] B.C.J. No. 1343 (S.C.), online: QL (CJ).

Christ Church of China v. Lee, [1986] B.C.J. No. 2685 (S.C.), online: QL (CJ). The injunction was upheld by the Court of Appeal: [1986] B.C.J. No. 1271, online: QL (CJ). 
Even with affiliation trusts there is a movement to stick with the express words of the trust and not go into implied territory at all. This tendency is illustrated by the Ontario Court of Appeal decision in 1989, which overturned a lower court decision that had implied a particular denominational affiliation. The Court of Appeal held that the original declaration of trust stated simply that the property was held for the benefit of "Macedono Bulgarians of the Eastern Orthodox Faith." This was wide enough to cover both the majority group who switched affiliation from one Orthodox denomination to another, and the minority group who insisted that the original affiliation had to be maintained. ${ }^{83}$ The lower court judge had decided that there was an implied trust that the church was to be under the ecclesiastical authority of the Russian Orthodox Church in Exile, and that the switch of the majority to the Macedono Bulgarian Eastern Orthodox Church was a breach of trust. This was based on a considerable amount of evidence about the founding and subsequent ideology of the congregation, but the Court of Appeal showed no inclination to imply even an affiliation trust. ${ }^{84}$ Without giving adequate reasons commensurate with the seriousness of the subject, the Court of Appeal even cited the American case of Jones v. Wolf ${ }^{85}$ to imply that the lower court had gotten involved in ecclesiastical matters not appropriate for secular adjudication.

On the other hand, the enforcement of an express affiliation trust, even against the wishes of a vast majority, was illustrated when several small congregations in rural Ontario, by nearly unanimous votes (with only one dissent), pulled out of the United Church after that denomination decided to ordain homosexuals. The United Church, relying on the legislation which had vested the churches into the United Church when they had voted to accept the union, went to court and claimed that the three churches belonged to the United Church and not to the three local congregations that had disaffiliated with the church. Even if everyone had decided to leave the United Church, they could not continue to use the church buildings, which either belonged to the higher denomination or were held in trust for it. The United Church was successful. ${ }^{86}$

Ogilvie contends that this case was wrongly decided by focusing only on the legislation and on the internal rules related to the holding of title. ${ }^{87}$ While the Union legislation may have displaced the local doctrinal trust, either express or implied, for purposes of the movement of property into the orbit of the United Church of Canada (UCC), Ogilvie argues that there is still an express doctrinal trust where the UCC holds that property in accordance with the terms of the Basis of Union, which includes doctrinal formulations like the Twenty Articles of Faith, and which did not make any provisions for the amendment of these doctrinal formulations. Up to this point Ogilvie appears to have a solid argument as to the enforcement of express doctrinal trusts. If indeed the local congregation holds the title to the property in trust for a higher denominational affiliation, but that denomination was itself bound by a certain 
confession in an unchangeable way at the time of affiliation and then has breached the confession, the local congregation may arguably disaffiliate and retain its property.

When one examines the argument that the confession has in fact been breached, however, one gets into the problem of interpreting more general provisions of a confession to say that a specific practice - in this case affirming homosexuals clearly violates this confession and that therefore the UCC has broken the express trust on which the local churches joined the Union. This may be entirely true as a matter of our theological opinion, but do we really think the secular courts are going to make a determination that affirming homosexuals is inconsistent with a much more general confession of faith that serves as an express trust? Even if one believed that the confession was broken, the last place that one would expect to be vindicated is in the Canadian secular courts. There is a difference between an express trust that says explicitly and clearly that all homosexual practice (as opposed to orientation) is rejected, and an express trust that talks about the authority of Scripture and the purpose of human sexuality. As we have seen with even express doctrinal confessions, the courts have bent over backwards to avoid making exclusionary judgments about whether the current interpretation of that confession is a diversion from it, even though it is unquestionably different from the original interpretation. The same express words are general enough or ambiguous enough for new interpretations, and I doubt that a court will award the property to the group that holds the original interpretation to the exclusion of the group that holds the new interpretation.

Contrary to this view, however, it should be noted that the Supreme Court of Bermuda decided a case involving a dispute over local church property valued at several million dollars. ${ }^{88}$ The local congregation was affiliated with the Wesleyan Methodist Synod of Bermuda, which in turn had been affiliated with the United Church of Canada since 1930. The local congregation, after exhausting internal appeals, voted by an 82 percent majority to pull out of the United Church affiliation. The Bermuda court accepted Ogilvie's argument that both express and implied trust principles required the court to examine theological doctrine to establish whether the United Church and the Methodist Synod had indeed departed from the original doctrinal trust. After hearing expert theological evidence, the court determined that the United Church and Synod had done so and the local church was awarded to the group that adhered more closely to the original doctrine. At the time of writing, the case is under appeal to a higher court. I could be wrong of course, but thus far we have seen very little evidence that a modern Canadian court would be willing to entertain a theological battle of experts involved in the interpretation of the Bible on human sexuality to enforce a generally worded doctrinal trust.

Returning to Canadian jurisprudence, to get a sense of which way the wind is blowing, note the dispute that took place over the assets of a Christian Reformed Congregation in Hamilton in 1993. The Synod of the Christian Reformed Congregation 
of North America decided to allow women to participate in various teaching and service positions in the church. This change was met with disfavour by the members of the local Church Council of the Mount Hamilton Church, who voted 92 percent in favour of disaffiliating with the mother church and establishing an independent Christian Reformed congregation. The division of opinion at the congregational level was certainly not quite so overwhelmingly in favour of disaffiliation, but nevertheless a substantial majority supported the church council. Unlike the United Church case, however, there was also a more substantially sized minority at the local level that wished to retain affiliation. Thus, the disaffiliation decision created a schism within the local congregation to the point where the two factions held separate meetings in the same building.

While the Christian Reformed Church (CRC) might be classified as hierarchical or at least denominational, with congregations affiliated into a higher conference, property is held by the local congregation. The conservative traditionalist majority group offered to split the assets on a pro rata basis with the minority liberal group and, at one point, they even offered to allow the minority group to have the existing building so long as pro rata compensation was paid to the larger group. As in the United Church case, however, the minority liberal "enlightened" group wanted the entire property. Thus the minority group eventually went to court and claimed that when the church was founded it was impressed with an implied trust that it was to be a congregation affiliated with the larger denominational church in North America, and that the corporation holding the church in trust should be controlled by the plaintiffs, rather than the group who had withdrawn from affiliation. ${ }^{89}$ Here, we have issues about the existence and scope of an implied affiliation trust, rather than an express trust as in the United Church case. While the defendant majority denied the existence of such a trust, they did not argue in the alternative that if there was one, a doctrinal trust should be implied on top of the affiliation trust, so that the court would have to determine whether the issue of liberalizing the role of women in the church breached the original doctrinal trust. In fact, in commenting on the absence of the implied doctrinal trust arguments, the judge made a statement that could have come from an American judgment:

\footnotetext{
Questions and issues of Doctrine and religious practice were not put before me for determination in this application. This is in accordance with precedent that such religious matters are not for a civil court to decide as the court may be driven to the impossible position of declaring who are the true believers and who are not. Non-interference has been the policy of the law long before the Charter and must. post-Charter, be emphasized. These questions were not put to this court: are not part of this application and are not to be read into the decision of the court. ${ }^{90}$
}

Justice Crane then suggested that there was no implied trust that the church had to affiliate with the larger CRC denomination, but rather that the express trust was simply for a Christian Reformed Church, which was a larger concept than the particular denominational affiliation in question. Again we see the reticence of the courts to imply trusts. 
Additionally in this case, in a refreshing change to the all-or-nothing pattern of property entitlements, the judge suggested that both sides of the schism were still members of the church and within the broad purposes of the trust. Therefore, under the authority of the Corporations Act, he could order that a vote should be held of the members as to a proposal identifying the members of the two factions, dividing the property equitably between the factions, and then deciding which of the two factions would leave with compensation and which would control the current church buildings. However, the plaintiff minority at the Hamilton church appealed to the Ontario Court of Appeal, which overturned the decision of the trial judge without resolving the substance of the dispute. ${ }^{91}$ It is important to note though that the Court of Appeal did not overturn the ruling that the trust might be wide enough to include both groups, or that dividing the property was a permissible judicial remedy. Rather, the problem was that there were inconsistent corporate bylaws as to who the members of the corporation were and thus the proposed vote could not take place without resolving that issue first. Not having the evidence before it to make a determination about the membership issue, the Court of Appeal simply overturned the lower court decision and the parties were left no further ahead then when the litigation started.

The liberal plaintiff minority started another lawsuit, and the motion by the majority defendants to have the case dismissed was rejected. ${ }^{92}$ While the preliminary motion to dismiss did not deal with the merits, there is a hint by the judge that perhaps the plaintiff minority who insisted that there was an affiliation trust might have the better chance at success. But no further proceedings apparently are reported and thus I assume that the courts did not resolve this dispute. However, we do see another example of reluctance to imply even an affiliation trust that would award the property to the local minority.

In another recent affiliation trust controversy, the judgment flirts with the idea of an organic trust in refusing to look at the founding date of the congregation as the point in time to construct the identity of the church in terms of giving shape to the scope of an implied trust. Absent an express trust to the contrary, we could pick a later point in time (but before the schism) in which we construct the identity of the church. An Alberta judge recently held that both factions of the congregation had agreed at an earlier point to change the focus of the church, disaffiliate with the Baptists, and join the Alliance denomination. ${ }^{93}$ After joining the Alliance, but in a probationary period for that affiliation, a schism at the local level took place and one faction was successful in being accepted by the Alliance, while the other faction was not. In giving the church building fund to the group that had achieved affiliation (it was not the group headed by the Pastor, and it may have been the smaller group) the court was not deferring to the judgment of the higher denominational authorities, but was rather identifying the successor group of the congregation, but within a context of the changed purpose of

Buma v. Sikkema, [1994] O.J. No. 2791 (C.A.), online: QL (CJ).

" Moum Hamilton Christian Reformed Church v. Sikkema, [1995] O.J. No. 1568 (Gien. Div.), online: QL (CJ).

4. Edmonton Korean Baptist Church v. Kim (1996), 189 A.R. 156 (Q.B.). 
that congregation through time. This seems to me to again put the courts some distance away from the originalist implied doctrinal trust concept.

Finally, in the most recent affiliation fight over church property in Canada at the time of writing, the Ontario courts have again illustrated that express affiliation trusts will be enforced, but that they are loath to imply anything. Rather, they display a desire to confine the case to the written documents and to avoid as much as possible any issues that might be better left to the ecclesiastical authorities. ${ }^{94}$ Despite overwhelming agreement among the Parish Council and the members of the congregation of the Holy Virgin Church in Ottawa to switch affiliation from the Russian Orthodox Church Outside Russia (ROCOR) to the Russian Orthodox Church within Russia, the court determined that the constitution and bylaws of the local corporation clearly tied the hands of the local parish in terms of their ability to switch denominations, because the documents clearly stated that the church was under the authority of ROCOR. The documents also indicate that all bylaw changes at the local level had to be approved by the Diocesan Bishop and ratified by the Synod of ROCOR.

But again, while the court affirmed that the church was under the jurisdiction of ROCOR, the court refused to grant declarations that the priest and vast majority of members who had switched affiliation were no longer members of the parish or eligible to sit on the Board or Parish Council. Making such a ruling would unnecessarily involve the court in religious determinations; again a Canadian court cited the American authority of Jones v. Wolf..$^{95}$ As an alternative, Panet J. turned to a section in the Canada Corporations Act which allowed the court to direct and supervise a shareholders meeting in extraordinary circumstances. Justice Panet then in effect ordered a kind of reaffirmation-of-membership process where only those who properly applied for membership back into ROCOR would be entitled to vote at the special meeting to elect a new Parish Council. In the meantime, until the new Council was elected, Panet J. put the Bishop of ROCOR in charge of the parish that overwhelmingly sought to leave his jurisdiction. One may doubt that this constitutes a minimum interference with religious affairs or is the end of the story,${ }^{96}$ but for our purposes, all of these determinations were made on the basis of the incorporating documents of both the mother church and the congregation and the constitutions and bylaws thereof, not on implied trusts of affiliation, and certainly not on the basis of any implied doctrinal trusts. Holy Virgin Russian Orthodox Church (Outside of Russia) in Ottawa, [2001] O.J. No. 438 (S.C.), online: QL (CJ).

is Supra note 85 .

\% Indeed, before the case even went to trial there were at least 13 motions heard. Some of these include Synod of Bishops of Russian Orthodox Church Outside of Russia v. Sever, [2000] 0.J. No. 2424 (Gen. Div.); [2000] O.J. No. 320; [2000] O.J. No. 190 (S.C.); and [1999] O.J. No. 4799 (C.A.), online: QL (CJ). 


\section{From Trust Doctrine to Review of CORPORATE GovernanCE}

One might note finally that there are many other cases of church property disputes in Canada, though not particularly relevant to our discussion of express or implied trusts. It is noteworthy, for example, that church property is increasingly dealt with under corporate law or charitable-society legislation. This type of legislation provides that property is usually controlled by the majority and it contains various rules goveming election procedures, eligibility to vote for positions of management, fiduciary duties of the managers to "shareholders," and so forth.

For example, the courts in British Columbia have been riddled with Sikh disputes to the same extent as the Manitoba courts have been riddled with Hutterite disputes. There has been violence and turmoil as to the control of the Temples between so-called moderate and fundamentalist factions. There has been litigation about who the voting members are and about the fairness of the elections. In the face of violence, the secular courts have issued injunctions, appointed interim executives, supervised elections and quashed resolutions, while Sikhs have sued each other for defamation. ${ }^{97}$ In these cases, the courts refer continuously to the provisions of the Society $A c t,{ }^{98}$ and to the specific procedural bylaws of the Sikh societies, but appear to avoid references to the ecclesiastical doctrines and disputes that give rise to the motives to engage in the voting struggles. We appear to have considerable judicial involvement in church affairs, but it is reduced in scope to the regulation and supervision of democratic procedures, rather than the determination of ecclesiastical doctrines. Courts are no doubt much more comfortable dealing with democratic procedural issues where the church is simply another corporation regulated by what amounts to secular procedural rules.

There has also been considerable litigation in Canada dealing with the various adjustments of affiliations and conflicts in Orthodox incorporated societies that hold churches in trust. These cases often have very little to do with religious doctrinal disagreements and have everything to do with ecclesiastical politics. Here, the struggles concern the boundaries of authority within the church as between parish and mother church. This raises questions as to why the courts should get involved at all in these disputes where members of the same church sue each other over essentially ecclesiastical politics, but use corporate or property law as a hook. It would appear that

A few of the recent cases include: Gill v. Dhillon, [1997] B.C.J. No. 384 (C.A.), online: QL (CJ); Bagri v. Sikh Cultural Society, [1997] B.C.J. No. 1770 (S.C.). online: QL (CJ); Gill v. Guru Gurobind Singh Temple Association, [1997] B.C.J. No. 207 I (S.C.), online: QL (CJ); Singh v. Gill, [1998] B.C.J No. 805 (S.C.), online: QL (CJ); Pannu v. Khalsa Diwan Society of Abbotsford, [1998] B.C.J. No. 1613 (S.C.), online: QL (CJ); Gill v. Bhandal (1998), 165 D.L.R. (4th) 151 (S.C.); Hara v. Khalsa Diwan Society - New Westminster, [1998] B.C.J. No. 2928 (S.C.), online: QL (CJ) and [1998] B.C.J. No. 1495 (S.C.), online: QL (CJ); Sohi v. Khalsa Diwan Society. [1999] B.C.J. No. 1299 (S.C.), online: QL (CJ); Khalsa Diwan Society of Abbotsford v. Sidhu, [2000] B.C.J. No. 600 (S.C.), online: QL (CJ) and [2000] B.C.J. No. 568 (S.C.), online: QL (CJ); Korotana v. Guru Gobind Singh Temple Assn., [2000] B.C.J. No. 628 (S.C.), online: QL (CJ); Gill v. Bhandal, [1999] B.C.J. No. 3115 (S.C.), online: QL (CJ); Bal v. Kular, [2000] B.C.J. No. 1941 (S.C.), online: QL (CJ). 
some Orthodox groups have been particularly litigious in this regard. ${ }^{99}$ But there are other examples in Canada of ecclesiastical lawsuits taken to secular courts, such as when two Anglican parishes sued each other to the Supreme Court of Canada over the use of a particular church house. Chief Justice Fitzpatrick's comments indicate both the typical Canadian expression of regret and acceptance of jurisdiction:

This is not a case ... of a schism leading to a separation into distinct and conflicting bodies; it is merely a contest between the inhabitants of two parishes, all of whom profess the same religious faith and acknowledge one ecclesiastical authority.... At first sight it would appear as if such a disagreement could have been settled at far less expense and much more satisfactorily by the proper church judicatories; but since the parties have chosen to litigate their differences in the civil Courts, it is our duty to inquire into the facts and decide the best of our ability the issues raised in the pleadings and evidence. $^{100}$

Another case of an ecclesiastical case that should never have gone to court is illustrated by a fight between the Bishop and the local church warden and vestry over a disagreement involving the appointment of a priest. ${ }^{101}$ In one of the many Greek Orthodox cases taken to litigation, O'Driscoll $\mathrm{J}$. was sharper with his regrets when he stated,

I can think of no problem less suited for a court-room and the adversary system than an internal disagreement amongst members of a religious denomination.... It always has been my view and still is my view, that all these problems should be settled in the ecclesiastical setting and not in the arena of a civil court. ${ }^{102}$

As noted, most of these so-called property cases involve the interpretation of constitutions and canons to review the regularity of various processes and do not involve allocating property to one faction or another based on any property trust doctrine. In one case, land was originally conveyed to the Archbishop of the Russian Greek Catholic Orthodox Church of New York and, after various schisms occurred within the upper echelons of the church, litigation was brought to court by two competing individuals both claiming to be Archbishop. ${ }^{103}$ The control of property was just a hook to have what was essentially an ecclesiastical dispute (about who was the Bishop of Canada) litigated in a court instead of settled in the church. There are disputes that involve property where there are no doctrinal issues or trusts at stake but where the courts will review the regularity of the procedures. This occurred when two (C.A.); Macedono-Bulgarian Orthodox Parish v. Elieff, [1964] O.J. No. 411 (C.A.), online: QL (OJ); Kotseff v. Elieff, [1964] O.J. No. 354 (H.C.), online: QL (OJ): Bourganis v. Glarentzos. [1977] O.J. No. 193 (H.C.), online: QL (CJ); Re Marmon, [1980] O.J. No. 1225 (H.C.). online: QL (CJ); Palmer v. Marmon (1978), 32 O.R. (2d) 417 (H.C.); Colettis and Greek Orthodox (1993), 107 D.L.R. (4th) 248 (B.C. S.C.); Demiris v. Hellenic Community of Iancouver. [2000] B.C.J. No. 907 (S.C.), online: QL (CJ). 
factions within a congregation disagreed about whether the insurance proceeds after the church was burned down should be used to build a new church at a new location or replace the church at the existing location. ${ }^{104}$ The courts also reviewed a case in which one faction at a synagogue alleged that the congregation had not properly approved the purchase of land by the trustees. ${ }^{105}$

Thus, in the end, I would argue in a tentative way that if there are express trusts, either of doctrine or affiliation that bind the factions, a Canadian court should enforce such trusts. Even in this category, the judiciary is flirting with American jurisprudence, seeking to avoid religious controversy in interpreting such trusts and only embracing that which seems clear and obvious. Secondly, while there is some continued support for an implied affiliation trust, there is a lack of supporting Canadian precedent for the traditional common law implied originalist doctrinal trust. Also, while there does not seem to be much in the way of precedent moving away from the all-or-nothing approach to allocating church property in the face of a schism, there does not seem to be anything in principle that stands in the path of a court dividing church property pro rata among the factions if indeed no express trust is breached by either faction but instead both factions are within the trust. Finally, the increasing citation to American authorities indicates that the gap between Canadian and American jurisprudence may be decreasing.

\section{The Judicial Resolution of Church Property Disputes in AMERICA}

For comparative purposes, I will now briefly outline three general approaches to the judicial resolution of church property disputes in the United States. These are the polity-deference, neutral-principles, and abstention models. The relationship between these models and the scope of their use in particular cases seems complex and confusing. ${ }^{106}$

\section{A. The Polity-Deference Model}

The deference approach arose most directly out of the competing jurisdiction of civil courts to resolve disputes dealing with property rights and the sovereign jurisdiction of ecclesiastical authorities to determine matters of church doctrine and government. The Supreme Court of the United States adopted the "polity-deference" approach in the 1871 case of Watson v. Jones. ${ }^{107}$ Here, the dispute arose between two factions at a Presbyterian Church in Kentucky. The property was held by local trustees, but there was no doubt that the church had always been a part of the larger Presbyterian Church of America. The General Assembly of the mother church had taken an anti-slavery position and supported the federal government in the civil war. In 1865, the General

Heine v. Schaffer (1905), 2 W.L.R. 310 (Man. K.B.)

Kopman v. Simonsky (1903), 2 O.W.R. 617 (H.C.).

A recent overview of the topic is provided in K. Greenawalt, "Hands off? Civil Court Involvement in Conflicts Over Religious Property" (1998) 98 Columbia L. Rev. 1843.

Watson v. Jones, 80 U.S. 679 (1871) [hereinafter Watson]. 
Assembly proclaimed that when people applied for membership or employment in churches under its jurisdiction they would have to repent if they had been sympathizers or supporters of the insurrection in support of slavery. Various southern churches had already withdrawn from the mother church and formed their own Presbyterian Church of the Confederate States and, with the declaration of 1865, more did so. At the Walnut Street Presbyterian Church in Louisville, the majority supported the position of the General Assembly but a significantly sized minority had supporters among the elders and trustees, as well as their own rival minister. This pro-slavery group was attempting to seize control of the local church and associate it with a rival Presbytery and Synod. Eventually two parties were before the court, each claiming to be the true Walnut Street Presbyterian Church. The problem ultimately found its way to the Supreme Court of the United States.

The court was presented with the English approach where, absent some express trust provisions in the land deeds or constitution of the church dealing with doctrine or affiliation, the courts should imply a trust so that the church goes to the faction (whether majority or minority is irrelevant) that best conforms with the original doctrine and affiliation, if any, that the church had when it was founded. ${ }^{108}$ This would mean that the court would have to establish what the various religious doctrines and affiliations of the church were and which party had substantially departed from them. The court would be thrown into the middle of the religious dispute if it had to decide whether or not imposing an anti-slavery test was a departure from and inconsistent with the original doctrine of the Presbyterian church at the time the Walnut Street Church was founded. Justice Miller for the court rejected the English implied trust doctrine. He suggested that the courts would in fact look at the terms of an express trust, even if it included religious doctrine, and adjudicate such trusts as terms of a contract, but the court would not imply religious trusts. Rather, he stated that in the absence of express trusts, the courts should first establish whether the religious organization is congregational or whether it is hierarchical.

If the polity is hierarchical, as it was in this case, the courts should simply defer to the decision of the highest church authority as to which group is entitled to the property, and the courts should then enforce this decision. Obviously, in most cases, the highest authority in a denomination will say that the local church belongs to those who are faithful to the denomination. In any case, what is crucial here is that the church decision is absolutely sovereign. The court will not exercise any review over it, not even to see if the rules of the hierarchical church were obeyed or if natural justice was followed in the process. The court will not get into the arguments that the denomination itself departed from the faith that existed at the time the local church affiliated with it.

On the other hand, if the polity is congregational, and there are no express provisions to the contrary, the court will use the constitution or bylaws of the organization to identify how decisions should be made. Usually this will be by majority vote of the members, but it may be by majority vote of a Board or even by the dictates of a spiritual leader. In any case, equal deference would demand that once this process is 
identified, the court should defer to the result of that process. The court will not hear arguments that the majority of the Board or congregation has departed from the faith. Thus, in most cases the polity-deference approach reduces to the simple principle that the state enforces the decisions of the highest authority or the authority of the majority, depending on the polity.

In rejecting the English implied trust model, Miller J. made a statement which is often cited as foundational for the abstention approach as much as for the deferential one:

In this country the full and free right to entertain any religious belief, to practice any religious principle, and to teach any religious doctrine which does not violate the laws of morality and property. and which does not infringe personal rights, is conceded to all. The law knows no heresy, and is committed to the support of no dogma, the establishment of no sect. The right to organize voluntary religious associations to assist in the expression and dissemination of any religious doctrine, and to create tribunals for the decision of controverted questions of faith within the association. and for the ecclesiastical government of all the individual members, congregations. and officers within the general association, is unquestioned. All who unite themselves to such a body do so with an implied consent to this government, and are bound to submit to it. But it would be a vain consent and would lead to the total subversion of such religious bodies, if any one aggrieved by one of their decisions could appeal to the secular courts and have them reversed. It is of the essence of these religious unions, and of their right to establish tribunals for the decision of questions arising among themselves, that those decisions should be binding in all cases of ecclesiastical cognizance, subject only to such appeals as the organism itself provides for. ${ }^{109}$

That is certainly a strong statement for the sovereignty of the church and particularly the tribunals thereof. But this is not abstention. Here, the force of the state can be used to enforce the mother church's decision that the Walnut Presbyterian Church obviously belonged to the faction that obeyed the anti-slavery position of the mother church. Those that disagreed would have to leave and build their own church. While this is not abstention, there is a strong abstention component to the deference model in the sense that the court is not reviewing the decisions made in the ecclesiastical sphere.

Getting rid of implied trusts has benefits and costs. We may well be faced with decisions in the church that are wrong and unjust, but there will be no remedy by running to secular law. For example, a local church might be part of a hierarchical church but there might actually be a well-settled expectation that the local church can withdraw and keep its own property; yet, if the highest tribunal breaches that implied, rather than express expectation, the courts will defer and not interfere. On the other hand, a congregational church, though not hierarchical, may still be affiliated with a higher association of churches with every indication that an implied trust to maintain that affiliation is expected; but if a congregation votes to disaffiliate, the courts will defer to that decision even if it is in breach of the implied trust. This is the cost of deference. But unlike abstention, where the courts refuse to intervene at all, here the courts may actively perpetuate the wrongs by enforcing them. 
Thus it is somewhat misleading to say that this model involves secular-law deference to the law of the religious community. Rather, it is secular-law deference to the outcome of the internal law process because, at least in regard to hierarchical churches, it would appear that the internal law might itself be broken and yet the courts will still enforce the decision if property rights depend on it. This was illustrated more than one hundred years after Watson, when the Supreme Court decided a case involving the ownership of diocesan property with rival bishops claiming control of it. ${ }^{110}$ After receiving numerous complaints about the bishop for the whole Serbian Eastern Orthodox Diocese of United States and Canada, the Serbian Orthodox Church headquartered in Belgrade, Yugoslavia - suspended the bishop and proposed to break up the huge Diocese into three separate ones, each with its own bishop. The suspended bishop claimed that the canon law of the church had been broken in terms of the process for his suspension and that, according to the internal law of the church, the Diocese could not be broken up without the approval of the Diocese itself. He thus refused to step down and relinquish control of the administration or property of the Diocese to the new administrator appointed by the mother church. For refusing the will of his superiors, the bishop was ultimately defrocked and a new bishop appointed. However, the disciplined bishop again claimed violations of canon law and he then purported to make the Diocese independent of the mother church.

The church was obviously hierarchical, and following the deference approach of Watson one would expect that the church property would go to the faction that obeyed the mother church's ruling. Nonetheless, the suspended bishop was successful in various claims that the mother church had not properly followed internal church law in suspending him or in making the decisions to create the three dioceses. The Supreme Court reversed and reinforced the polity-deference model. Justice Brennan stated,

For where resolution of the disputes cannot be made without extensive inquiry by civil courts into religious law and polity, the First and Fourteenth Amendments mandate that civil courts shall not disturb the decisions of the highest ecclesiastical tribunal within a church of hierarchical polity. but must accept such decisions as binding on them, in their application to the religious issues of doctrine or polity before them. ${ }^{11 \prime}$

The idea that the courts would simply enforce the decisions of the highest church tribunals, even when the law of the church itself might well have been violated, did not sit well with Rehnquist J., who wondered why the courts should be "handmaidens of arbitrary lawlessness." 112 While affirming that the courts could not determine religious issues in the process of settling property disputes, Rehnquist J. rejected the majority's refusal to even minimally review the legality of decisions in terms of conformity to the internal legal norms of the "sovereign" church:

Such blind deference. however, is counseled neither by logic nor by the First Amendment. To make available the coercive powers of the civil courts to rubber-stamp ecclesiastical decisions of hierarchical 
religious associations, when such deference is not accorded similar acts of secular voluntary associations, would, in avoiding the free exercise problems ... itself create far more serious problems under the Establishment Clause. ${ }^{113}$

In reality, however, the deference model does not mean that there is no judicial review of the internal law of the religious group before decisions are implemented. Despite the absolutist statements about the lack of jurisdiction to review religious law, either hierarchical or congregational, there was actually a minimum level of review that the courts developed. In Bouldin v. Alexander ${ }^{1 / 4}$ in 1872, the Supreme Court stated,

we cannot decide who ought to be members of the church, nor whether the excommunicated have been regularly or irregularly cut off. We must take the fact of excommunication as conclusive proof that the persons exscinded are not members. But we may inquire whether the resolution of expulsion was the act of the church, or of persons who were not the church and who consequently had no right to excommunicate others. ${ }^{115}$

In other words, there has to be enough of a review to see if the ecclesiastical tribunal is actually the tribunal or an imposter. That is, without implying doctrinal or affiliation trusts, does the tribunal actually have the authority to give the commands to which we will defer? For example, the lowa Supreme Court dealt with a situation where some deacons were expelled from membership in a Baptist church (congregational) without any formal notice of charges and without any hearing being given to them or any opportunity to respond. Yet, so long as this was done by majority vote, the court declined to impose any requirement of natural justice or even of procedural conformity with internal law. ${ }^{116}$ The tribunal was the majority. However, when Baptist members were expelled by the Board of Deacons and Trustees, rather than by the majority vote of members, the Supreme Court of South Carolina voided the expulsion in the absence of evidence that the Board had the jurisdiction to expel. The court stated,

It is not for this court to determine who shall or shall not be members of the Mount Zion Baptist Church. It is not for this court to dictate procedure for the church to follow. It is the function of this court, however, in these circumstances, to assure that the church itself has spoken. If it has, the court inquires no further. If it has not, this court may restore the status quo to enable the church to act. ${ }^{117}$

This is consistent with an earlier South Carolina case where the minister of a Baptist church refused to step down after an alleged majority of the congregation voted to

Ibid. at 2392.

Bouldin v. Alexander, 82 U.S. 131 (1872).

Ibid. at 139-40 [emphasis added]. In Trustees of Oak Grove Missionary Baptist Church v. Ward, 86 S.W. 2d 1051 (Ky. C.A. 1935), the court held that a minority of the Baptist congregation could not expel a majority.

Brown v. Mt. Olive Baptist Church, 124 N.W. $2 d 445$ (lowa Sp. Ct. 1963). See also Mangum v. Swearingen, 565 S.W. 2d 957 (Tex. C.A. 1978), where process to expel Deacons may not have followed proper procedures but a majority of the church nevertheless voted to expel.

Bowen v. Green, 272 S.E. $2 d 433$ at 435 (S.C. S.C. 1980). In a similar vein of taking only limited jurisdiction to establish the authority to act, see Gillespie v. Elkins Southern Baptist Church, 350 S.E. $2 d 715$ (W. Va. C.A. 1986). 
terminate his position. Various trustees successfully sued to get a restraining order to prohibit the minister from entering the pulpit. The court did not abstain in the true sense by saying that this was an ecclesiastical dispute and by refusing to help either party. Indeed, the chaos in the church was so great that the court ordered the church to be locked up and not to be used by either faction until the court determined whether the minister had been removed. After the court invoked the power of the state to enforce the majority right to terminate the minister, the minister appealed. The court stated,

this court will consider whether the church has ordered his exclusion. not whether it was right in doing so. Neither will the court. as a civil tribunal, undertake to determine whether the resolution directing exclusion was passed in accordance with the canon law of the church, except in so far as may be necessary to do so in determining whether it was in fact the church that acted. ${ }^{118}$

Despite the very limited judicial review proclaimed in these cases, if the court has to at least determine the body with internal legal jurisdiction, we are in some cases at least a half-circle back into judicial examination of ecclesiastical matters in terms of canon law or provisions in constitutions and bylaws with religious content. It should be remembered that the original polity-deference approach does not prevent courts from interpreting express trusts even if they have religious content. What was rejected was implied trusts. Judicial review of the internal law of the organization will be especially important in non-hierarchical polities. What will frequently happen in congregational matters is that rival meetings will be called: one meeting of the church votes to retain the minister and another meeting votes to terminate. Then the factions fight over the use of the property. Thus, the court has to at least determine which of the meetings was properly called in terms of the constitution or customs of the church. ${ }^{119}$ Another issue will often involve whether the persons present at the meeting were properly members of the church with voting rights and whether there was a quorum. The Alabama Supreme Court held that a vote to oust the pastor was valid even though the pastor purported to adjourn the meeting and left with his supporters after which the remaining members elected their own moderator and unanimously voted to remove the minister. ${ }^{120}$ The Florida Court of Appeal was faced with the same scenario in another case and came to the same conclusion. ${ }^{121}$ Under this minimal review of simply establishing the authority to act, some courts will actually supervise the vote of a congregational church to then enforce the decision. ${ }^{122}$ The deference approach, despite being a model of church sovereignty, begins to look like what occurs in many Canadian cases. It is worth remembering, however, that beyond reviewing the jurisdictional authority of the body, the deference approach - at least in its purest form - does not

Morris Street Baptist Church v. Dart, 45 S.E. 753 (S.C. 1903) [emphasis added].

See, e.g., Graham v. Lockhart, 256 S.E. 2 d 518 (N.C. C.A. 1979).

Foster v. St. John's Baptist Church, 406 So. 2d 389 (Ala. S.C. 1981).

Covingion v. Bowers, 442 So. 2 d 1068 (Fla. C.A. 1983).

A court-supervised vote was held in Beulah Missionary Baptist Church v. Spann, 346 N.W. 2d 911 (Mich. C.A. 1984). A court ordered a new vote of the congregation for members of the Board of Directors who then could retain or fire the minister in First Union Baptist Church v. Banks, 533 So. 2d 1305 (Lo. C.A. 1988). 
impose external law concepts of procedural justice, nor internal law compliance beyond jurisdictional issues, and it certainly does not second-guess the merits.

Other commentators have pointed out the merits and demerits of the deference approach. ${ }^{123}$ Arguably, the complete deference to the decision of the hierarchy without any review is inconsistent with the usual pattern of judicial review, however minimal, that is required to "find the body" in a congregational organization. Thus, the two polities are perhaps not dealt with equally. This means that drawing the distinction between congregational and hierarchical becomes itself a critical part of the decision and outcome. It is at least uncertain in some cases, including the Hutterite scenario, for example, whether a polity could be classified congregational or hierarchical. Mere affiliation alone does not create a hierarchical church, although there may still be enforceable express trusts requiring the congregational church to affiliate with a particular denomination. It is some degree of control over the local church that separates the congregational from the hierarchical, but the degrees of control and the matters over which the hierarchy has control can vary greatly between different religious organizations. Another problem, as already noted, is the tension of simply enforcing ecclesiastical judgments to preserve the separation of church and state and, yet, the possibility that by so doing the coercive power of the state is being used to aid one or the other side of a religious dispute - an action which arguably violates the separation of church and state.

Finally, the problem of express trusts is left dangling. We know that the deference approach rejected the implied original doctrinal or affiliation trust. But as to express trusts, the implication of Watson was that the courts need not defer to the ecclesiastical authorities if there was an express trust, whether dealing with doctrine or affiliation or both. Rather, the courts could enforce such trusts against the ecclesiastical authorities that breach them. The courts can hold the ecclesiastical authorities accountable to obey their own express internal legal contracts, as it were, at least in regard to property trusts. Thus if the mother church ordains women and the local church has an express trust in the property deed that the church shall not ordain women, rather than deferring to the judgment of the mother church that the property should go to the faction that supports the mother church, the court can say that the mother church departed from the trust, at least in regard to this property. If there is an express trust we do not use the polity-deference approach, but rather apply the trust terms. This was the implication of Watson. In fact, this was not how the deference model ultimately evolved.

For many years state courts enforced express doctrinal trusts, even implying details onto very general purpose statements, especially in congregational settings where there were no higher church tribunals to which to appeal. Property might be awarded to the minority of the Baptist congregation because the majority had departed from fundamental Baptist doctrine, ${ }^{124}$ or it was the minority that was judged to have departed from the fundamentals of the trust. ${ }^{125}$ Sometimes, if neither group had 
departed from the trust but could not live together and were fairly evenly divided, the court would divide the property between the two groups instead of giving it to the bare majority. ${ }^{126}$ An express doctrinal trust might also bind a hierarchical church. Higher authority should not get away with breaching an express trust any more than a lower majority. Assuming that the court takes jurisdiction in the first place, it seems sensible to enforce express trusts.

If the court does not enforce express doctrinal trusts, a majority can get away with anything and divert a Baptist church into a Rotary Club, for example. It would seem manifestly unfair not to question the excommunication of members when the purpose of the excommunication is to get rid of those who are faithful to the doctrinal trust so that a majority can ultimately achieve a diversion. ${ }^{127}$ But the difficulty, as I have argued, is that most express doctrinal trusts are neither specific nor easy to interpret. More likely, there is reference to a general confession, and then some faction claims, for example, that ordaining women violates the trust. Because the courts have repeatedly stated that under the First Amendment courts are not supposed to determine matters of ecclesiastical doctrine or government, even express doctrinal trusts in many cases are simply unenforceable by secular courts. Again, we are back to deference. If the doctrinal departure is anything but obvious, the issue as to whether the express trust is broken or not is a matter to be adjudicated in the ecclesiastical courts. The doctrinal trust must be viewed as a part of the internal ecclesiastical law, not as an enforceable term of outside contract or property law capable of independent judicial enforcement. At least this would appear to be the case unless the terms are absolutely plain and unambiguous.

While the Supreme Court heard a series of cases after Watson, ${ }^{128}$ the limitation on adjudicating express trusts with religious terms was not addressed. However, in 1970, in a minority concurring judgment, Brennan J. asserted that the enforcement of "express terms" as used in Watson should mean that "only express conditions that may be effected without consideration of doctrine are civilly enforceable," and that "any language in Watson that may be read to the contrary must be disapproved." 129

However, while courts cannot imply doctrinal trusts and are now severely limited in adjudicating express doctrinal trusts, it should be remembered that nothing in the politydeference approach took away the authority of courts to enforce express affiliation trusts. For example, if a term in the land deed or constitution required a particular congregation to be affiliated with the Mennonite Brethren denomination, the courts

Immanuels Gemeinde v. Keil. 58 P. 973 (Kan. S.C. 1899).

Smith v. Pedigo. 44 N.E. 363 (Ind. S.C. 1896). Here. the court finds departure because the majority faction adopts the value of missionary work which supposedly violates the doctrine of election-predestination (one cannot help God do His work) that supposedly is part of the doctrinal trust of the Regular Baptist congregation.

Gonzalez v. Roman Catholic Archbishop of Manila. 280 U.S. 1 (1929): Kedroff v. St. Nicholas Cathedral of the Russian Orthodox Church in North America, 344 U.S. 94 (1952); Kreshik v. St. Nicholas Cathedral of the Russian Orthodox Church in North America. 363 U.S. 190 (1960). Maryland and Virginia Eldership of Churches of God v. Church of God at Sharpsburg. 90 S.Ct. $499(1970)$ at 501. n. 2. 
could enforce that term, even if the vast majority of the congregation decided to disaffiliate and become an independent Mennonite Church or join a different Mennonite denomination, or cease to be Mennonite altogether.

\section{B. The NeUtral-Principles MOdel}

Eventually the Supreme Court gave its blessing to another model for the resolution of church property disputes. The roots of an alternative model were already laid down in another Presbyterian dispute taken to the Supreme Court in 1969. ${ }^{130}$ Two Presbyterian churches in Savannah, Georgia voted in 1966 to withdraw from the mother church, the Presbyterian Church in the United States. After failed attempts to bring the congregations back into the fold, the mother church took control of the churches until new local trustees and officials loyal to the mother church were in place. The two churches sued in the state courts, claiming that there was an implied trust that the affiliation with the mother church was conditional on that church not departing fundamentally from the doctrine that it had when the local churches affiliated with it. It was argued that the mother church had substantially departed from the terms of the trust by accepting the ordination of women, making pronouncements in the political arena, affiliating with liberal ecumenical organizations, adopting various publications that departed from the theological, moral, and ethical standards of the faith, and so forth. The Georgia courts allowed the issue of departure from the implied trust to go to a jury. In the end, the two churches were awarded to the majority faction that withdrew from the mother church, rather than to the faction that supported the mother church.

Not surprisingly, the Supreme Court of the United States again rejected the implied doctrinal trust approach as a violation of the First Amendment. By adjudicating whether the mother church has departed substantially from an original implied trust, and then identifying whether the departure relates to something of such fundamental importance to the faith as to amount to a breach of the trust, the courts become entangled in religious determinations. While rejecting any role for the courts in determining ecclesiastical questions in the process of deciding property disputes, Brennan J., for a unanimous court, did not simply apply the polity-deference approach as the model that the state of Georgia had to use. Rather, he suggested that

\footnotetext{
there are neutral principles of law, developed for use in all property disputes, which can be applied without "establishing" churches to which property is awarded. But First Amendment values are plainly jeopardized when church property litigation is made to turn on the resolution by civil courts of controversies over religious doctrine and practice. ${ }^{131}$
}

Justice Brennan did not elaborate on what these neutral principles of law were, but certainly the reference to "neutrality" implies that a court might be able to decide a case by looking at the express terms of the title deed or at other documentation, without making any determination of any religious issues and without necessarily using the 
deference approach. As noted previously, however, one could hardly say that express doctrinal trusts are necessarily any more neutral than implied ones. In a concurring judgment, Harlan J. tried to put in one last plug for express doctrinal trusts. He added his view that the decision should not be read as invalidating the application of express trusts having religious content, at least if the conditions in such cases are clearly and expressly laid down. ${ }^{132}$ The fact that no one else joined this opinion may be indicative of the distaste that the American courts have for any doctrinal trust, whether express or implied, as opposed to an affiliation trust, which can be enforced simply because it says that congregation $\mathrm{X}$ must be affiliated with group $\mathrm{Y}$.

However, the rejection by the court of the claim advanced by the majority faction of the local church - namely that the mother church had departed from a doctrinal trust - did not mean that the faction that supported the mother church would necessarily win. Rather, the application of neutral principles to the case might proceed to find that the legal title to the local property was in the local corporation and, if there was no express trust in favour of the connection with the mother church, even if that connection and control had always been exercised, the local church might be entitled to withdraw and keep the property so long as that decision was properly made according to the "neutral" norms establishing authority at the local level, which usually would be by majority vote. Indeed this was the result when the case was remanded back to the state courts. ${ }^{133}$

In 1979, the neutral model was fleshed out by a bare majority in a badly divided Supreme Court. The decision of Jones v. Wolf ${ }^{134}$ involved another Presbyterian church, which was split between a majority who withdrew affiliation with the mother church and a minority who wished to retain affiliation. The Georgia courts used a socalled neutral-principles method and awarded the property to the local church majority because there was no express trust in favour of affiliation, even though the church was in fact a member of a hierarchical church. Thus, the courts did not defer to the opinion of the highest church tribunals that the true beneficiary of the trust was the minority faction that was loyal to the mother church. Rather, the Georgia courts used a supposedly "neutral" application of property law to determine that the local congregation held the title to the church and that no declaration of trust in favour of the general church existed in the documents of the local church or in the constitution of the general church, at least at the relevant time.

While remanding the case back on certain issues dealing with the locus of congregational authority, the Supreme Court upheld the neutral-principles method. Justice Blackmun stated,

The State has an obvious and legitimate interest in the peaceful resolution of property disputes, and in providing a civil forum where the ownership of church property can be determined conclusively. It is clear, however, that "the First Amendment severely circumscribes the role that civil courts may

13) Presbyterian Church v. Hull, 167 S.E. 2 d 658 (Ga. S.C. 1970), appeal refused 396 U.S. 1041.

13. Supra note 85. 
play in resolving church property disputes." Most importantly, the First Amendment prohibits civil courts from resolving church property disputes on the basis of religious doctrine and practice. As a corollary to this commandment. the Amendment requires that civil courts defer to the resolution of issues of religious doctrine or polity by the highest court of hierarchical church organizations. Subject to these limitations, however, ... a State may adopt any one of various approaches [including neutral principles] for settling church property disputes so long as it involves no consideration of doctrinal matters. $^{135}$

Rather than deferring to the congregational majority or hierarchical tribunal (after a minimal judicial review to see that the proper congregation or tribunal has acted), the neutral approach looks at the constitutional documents, bylaws, property deeds, and even canons of the church. If the entitlement to property can be determined from these documents, without any reference to disputed matters of religious doctrine or governance, a court may do so. But what if the dispute is essentially about a departure from an express doctrinal trust, or the documents are riddled with religious concepts? The neutral method was never suggested as a method by which courts could resolve all property disputes arising in religious organizations, but only some disputes. When neutral principles are inappropriate, a court must fall back on deference or abstain altogether.

In affirming the use of neutral principles as an option, Blackmun J. noted the limitations of this approach:

The neutral principles method ... requires a civil court to examine certain religious documents, such as a church constitution, for language of trust in favour of the general church. In undertaking such an examination, the civil court must take special care to scrutinize the document in purely secular terms. and not to rely on religious precepts in determining whether the document indicates that the parties have intended to create a trust. In addition, there may be cases where the deed. the corporate charter. or the constitution of the general church incorporates religious concepts in the provisions relating to the ownership of property. If in such a case the interpretation of the instruments of ownership would require the civil court to resolve a religious controversy, then the court must defer to the resolution of the doctrinal issue by the authoritative ecclesiastical body. ${ }^{136}$

It would appear that, whether the model is deference or neutral principles, a majority of the court was rejecting a secular court resort to any express doctrinal trusts, which are obviously not neutral nor secular, but are by definition religious matters outside the jurisdiction of the courts. ${ }^{137}$ Such matters must be left to the ecclesiastical authorities. The implication is that a court taking a neutral approach should switch to deference or abstention if an express doctrinal trust is found and not proceed on some other "neutral" basis to determine the legal entitlement to the property.

Ibid. at 602 [citations omitted] [emphasis added].

Ibid. at 604 .

In one recent case, however, the Alabama Supreme Court affirmed the application of an express religious trust when a majority faction of the church. including the minister, had apparently used the church property to advance the interests of a non-Christian organization called the League of the South. See Murphy v. Green. [2000] WL 1842406 (Ala. S.C.). online: WL. 
In Jones v. Wolf, Powell J., in dissent, argued that the court should continue to use the polity-deference model. He pointed out that the majority's assertion that the case was being decided without deciding religious matters was simply false. If the local church was in fact affiliated with the mother church, which was certainly the expectation and practice of the members from the beginning, and the majority group was in fact leaving the mother church due to disputes over doctrine, which was the case here, the award of the church to the local majority through the application of neutral principles of law, while ousting the faithful minority, was hardly a "neutral" application of legal principles just because there was no express affiliation trust. In Powell J.'s words,

The Georgia courts, as a matter of state law, granted control to the schismatic faction, and thereby effectively reversed the doctrinal decision of the church courts. This indirect interference by the civil courts with the resolution of religious disputes within the church is no less proscribed by the First Amendment than is the direct decision of questions of doctrine and practice. ${ }^{138}$

The dissenting minority of the Supreme Court would have rejected neutral principles and retained deference as the only acceptable method. The proper way to resolve church disputes is to decide which polity the church members themselves agreed to. Once the polity is established, one must follow the decision that the polity itself has made in regard to the property, even if the polity has departed from original religious doctrine, express or implied, or even if the church has not followed its own inside law in making the determination. The members have married the polity, as it were, and if that polity makes decisions that are unfaithful to them, or does not meet their expectations, they may leave, but a court will not grant them a property remedy. It is not the court's role to ensure the faithfulness of churches to their own religious norms.

When the case was remanded, the Georgia courts again applied the neutral-principles approach and affirmed that the local church, even though within a hierarchical polity, was not subject to an express trust of affiliation. In fact, it was controlled by majority vote at the local level, and thus the property was in the hands of the majority that had left the mother church. ${ }^{139}$ This indicates of course that, at least in some cases, the two approaches lead to different results. Because the Supreme Court did not mandate a neutral-principles method, but rather suggested that state courts could use either the traditional polity-deference approach or the new neutral-principles approach if it were possible to resolve the dispute that way, civil courts in the United States may now give totally different results depending on the method used. Subsequent American cases are all over the map in a mass of conflicting judgments, in which some jurisdictions use neutral principles and some use only deference. ${ }^{140}$ On essentially the same facts and church documents, some courts have found that the local church is held in trust for the denomination or the faction affiliated with it, while other courts have found that such a trust has not been proven and the local church is free to disassociate and retain the

\footnotetext{
1.R Wolf, supra note 85 at 613.

13i) Jones v. Wolf, 260 S.E. 2 d 84 (Ga. S.C. 1979).

1411 J.E. Fennelly, "Property Disputes and Religious Schisms: Who Is The Church?" (1997) 9 St. Thomas L. Rev. 319.
} 
property. Courts disagree as to how express the affiliation trust must be before the property is assigned to the higher denomination, rather than retained by a local congregation that leaves the denomination. ${ }^{141}$

The adoption of a neutral approach, rather than deference, probably has the most impact in cases involving affiliation disputes, particularly in hierarchical churches. There were a flurry of cases in which, under the deference approach, the mother church itself, or a local minority loyal to the mother church, would have retained the property while, under the neutral-principles approach, the withdrawing majority faction was allowed to keep the property. ${ }^{142}$ Why? Well, simply because there was no express affiliation trust in the local incorporation property deeds, or constitutions, or bylaws, even though the local church might always have been under the authority of a mother church or associated with a denomination. In regard to schisms in congregational (rather than hierarchical) churches, it is doubtful that the neutral-principles model would lead to significantly different results, given that the deference model usually means judicial review of the locus of authority of the congregation, which might be seen as a kind of neutral-principles approach to begin with.

Interestingly, there appears to be a movement away from the initial neutral-principles presumption that, if the foundational documents were not stamped with an express affiliation trust, one does not exist. Arguably, blind deference to ecclesiastical authorities is much better than this kind of narrow "neutral blindness" of legalism unconnected to reality. The Canadian approach of implying affiliation trusts in some circumstances seems more sensible. In the absence of doctrinal trust questions, why should we give the property to a withdrawing faction when that faction itself has participated in and acknowledged the authority of the higher church for years? What if that faction has itself participated in various changes in doctrine or taken matters to higher tribunals in the past? But now, after the higher church is ordaining women or homosexuals, should we allow the dissenting faction to, in effect, argue that there never was an affiliation trust, because one hundred years ago no one thought it necessary to put it into the local documents of incorporation? The neutral approach may delight schismatics, but one would think that some kind of estoppel might be called for. Indeed, what we are seeing is a movement, in some jurisdictions, to the acceptance of implied affiliation (not doctrinal) trusts under the so-called neutral method. This again might indicate that the gap between Canadian and American jurisprudence is not as great as might be thought.

There may be no express words that demand affiliation, but if we look at the circumstances related to the creation of the church in question, at the actual way the

141

See P. Gerstenblith, "Civil Court Resolution of Property Disputes Among Religious Organizations" (1990) 39 American Univ. L. Rev. 513 for an argument for more explicit evidence before a trust is declared.

14: Just a few of the cases I have examined include Protestant Episcopal Church in the Diocese of Los Angeles v. Barker. 171 Cal. Rptr. 541 (Ct. App. 1981); Piletich v. Deretich (Serbian Eastern Orthodox), 328 N.W. 2d 696 (Minn. S.C. 1982); Presbytery of Beaver-Butler v. Middlesex Presbyterian Church, 489 A. 2d 1317 (1985); Mikilak v. Orthodox Church, 513 A. 2d 54I (Pa. Cmwlth. 1986); Board of Bishops v. Milner, 513 A. 2d 1131 (Pa. Cmwlth. 1986). 
property was used, at the historic relationships between the denomination and the local church, and at the implications that can be drawn from the formal documents, a court might say that it was clearly intended that the local church be affiliated with a certain mother church or denomination. Even with the possiblity of looking at evidence of implied affiliation trusts, there are still cases where, under the neutral-principles approach, the higher church faction has lost, while it might well have won under deference. ${ }^{143}$ However, in other cases the higher church or faction loyal to it has received control of the property, even under neutral principles, because there is an implied trust of affiliation. ${ }^{144}$ While these cases might have been decided the same way under deference, congregational polity cases could exist where a court might imply an affiliation trust leading to a result different from a result if deference was used, at least if deference rejects all implied trusts, even affiliation trusts.

The acceptance of implied affiliation trusts, while sensible, may add some confusion to the analysis. If accepted by the neutral-principles model, how does the deference model deal with implied affiliation trusts? One account might be that, in the absence of an express affiliation trust, which is enforceable in any case, the deference court has to determine the polity and, obviously in that determination, the court will be looking at the same evidence that might lead to a court enforcement of an implied affiliation trust under the neutral method. Under this account, the deference court might still defer to ecclesiastical tribunals to decide such matters if the affiliations are implied rather than express. This would parallel the deference to ecclesiastical tribunals to decide doctrinal trust matters. At the same time, another model of deference might argue that there is no need to defer if the dispute squarely deals with an affiliation issue. Just as express affiliation trusts are enforceable, why should not implied ones be?

Due to our limited comparative purposes, it is not necessary to delve into these matters any deeper. Arguably, the embrace of implied affiliation trusts may in some cases give a result that is more in keeping with inside law, but at the same time we have perhaps more uncertainty and unpredictability as to what the results will be. Furthermore, if the neutrality method is premised on a separation of secular and religious provisions in church documents, we may well question such an assumption. ${ }^{145}$ By looking only at one set of internal rules, a court may be applying so-called neutral principles in a way that runs contrary to the actual expectations of the parties, even of those who may win the case.

143 See, e.g., a few recent cases involving implied affiliation trusts where the local won over the higher: Mt. Olive African Methodist Episcopal Church v. African Methodist Episcopal Church, 703 A. 2d 194 (Md. C.A. 1997); Scotts African Union Methodist Church Protestant Church v. Conference of African Union, 98 F. 3d 78 (Fed. C.A. 3rd 1996); Church of God Pentecostal Inc. v. Freewill Pentecostal, 716 So. 2d 200 (Miss. S.C. 1998).

145 See, e.g., a few recent cases involving implied affiliation trusts where the higher won over the lower: Bishop and Diocese of Colorado v. Mote, 716 P. 2d 85 (Col. S.C. 1986); Shirley v. Christian Episcopal Methodist Church, 748 So. 2d 672 (Miss. S.C. 1999); East Lake Methodist Episcopal Church v. Peninsula-Delaware Annual Conference, A. 2d 798 (Del. S.C. 1999); TrinitySt. Michael's Parish v. Diocese of Connecticul, 620 A. 2d 1280 (Conn. S.C. 1993).

its See N.C. Belzer, "Deference in the Judicial Resolution of Intrachurch Disputes: The Lesser of Two Constitutional Evils" (1998) 11 St. Thomas L. Rev. 109. 


\section{The AbStention Model}

In numerous cases dealing with membership issues, clergy issues, and even property issues, the American courts have refused to take jurisdiction over the dispute in the first place because, even if the parties invoked outside law concepts of contract, tort, or property, the cases simply could not be decided without getting into examinations and determinations of matters that are within the sovereign territory of the church. The First Amendment has been interpreted in a way that severely limits the reach of external law into the territory of the internal law of religious communities and organizations. It is really in this third model that we see the ultimate difference between Canadian and American approaches.

Abstention often relates to the kind of reasons that the plaintiff faction gives for why the court should award the property to them, or why the court should enforce their wish to have exclusive possession and exclude those who have been excommunicated. If the reasons are essentially that the defendant faction has departed from religious doctrine, and therefore are breaching some express or implied doctrinal trust, it is now wellestablished that civil courts in America will not adjudicate such doctrinal trusts. For example, when the plaintiffs claimed that they should be given control over the property of a Baptist church because they were the faithful members, while the defendant majority had departed from the faith and affiliation of the church, the North Carolina Supreme Court admitted that in the past the courts had enforced doctrinal trusts, but now doing so was not permitted as a matter of keeping the courts out of the affairs of the church. As the court stated,

Pressed to its logical conclusion, such a judicial inquiry becomes a heresy trial. Such trials may not properly be conducted by any civil court, state or Federal, in view of the First Amendment to the United States Constitution. ${ }^{146}$

In the same vein, the California Court of Appeal stated that the court had no jurisdiction to hear a property dispute based on the allegations that the defendants had departed from the previous "Unity" doctrines of the church and adopted "Charismatic" doctrines instead. ${ }^{147}$ In another case, when a majority group attempted to enforce the ouster of a minister, the lower court supervised a new vote between anti-pastor and propastor forces and even authorized police supervision of the vote. Presumably, after such a vote, the court would have granted an injunction to force the minister out of the pulpit if he had lost. However, the Texas Court of Appeals took a true abstention approach and said this should not have been done. ${ }^{148}$

Again, if we say that the disputants cannot go to civil courts to determine who has the right to control church property, we are in effect conceding that, in some cases, property may well be controlled by those who, according to the internal law of the religious community, ought not be in possession. When struggles for control involve 
prolonged tensions, chaos, and even violence, the courts have a hard time justifying abstention. The role of courts to serve society in the peaceful resolution of disputes clashes with the American notion that there is a boundary between the state and the church. However, it is difficult for a court to close the door to resolution when disputes within the church involve anti-pastor and pro-pastor factions heckling each other and attempting to stop each other from transacting business. ${ }^{149}$ Can a court really abstain when a minister refuses to leave the pulpit after being voted out by a majority? ${ }^{150}$

In Hutterite cases like Poinsett ${ }^{151}$ and Tschetter, $^{152}$ we may presume that the claim to property was framed in such a way that it was impossible to use either politydeference or neutral principles to adjudicate it. The claim by Group One minorities that they were the true Schmiedeleut and that Group Two had left the fold by disobeying the Elder could not be adjudicated without interpreting the express affiliation and doctrinal trusts in the Articles of Association of the colony and in the Constitution of the higher church, though these documents were riddled with religious doctrine. It would be absurd if the neutral model meant that a court could decide a case by looking only at "neutral" provisions of a constitution, such as a provision for membership by majority vote, and then simply ignore other provisions that have a religious content, and that plainly set a condition on the exercise of the so-called neutral "secular" provisions. I would argue, for example, that the existence of an express doctrinal trust should mean that the court cannot decide the case by the neutral principles of law method. The court is not aiding the cause of religious freedom and autonomy of religious groups by secularizing their disputes rather than properly contextualizing them. If the court is prohibited from religious contextualization, it should either defer to the ecclesiastical judgment about the meaning of the trust or abstain altogether. The court cannot determine by secular principles of interpretation which faction is living according to the proper norms of the Hutterian Church.

Justice Gilbertson in Tschetter, however, gave a different reason for rejecting the neutral method, which is just as good. He concluded that in this case there was just no way that a court could separate any secular provisions from religious provisions. The Hutterian corporate documents were simply pervaded with religious concepts, and this was consistent with the nature of Hutterite life where "there is no separation of religious life from a secular life in a Hutterite colony because there is no separate secular life." 153

On the other hand, one might wonder why the deference model could not be applied to the Hutterite cases. One possibility is that these cases, at least in terms of property entitlements, were just not framed in such a way. Thus, for example, if it had been the majority Group Two who had launched the lawsuit to expel the minority Group One supervised election, a minister refused to step down from the pulpit and was ultimately jailed for contempt of court for refusing to obey a court order obtained by the congregation. 
faction, the plaintiffs might have argued that the court could ignore all the express doctrinal trusts and simply look at the polity. If the polity was congregational, Group Two would win because they were the clear majority. If the polity was hierarchical, Group Two would also win because it was recognized by the highest church as the proper successor of the Schmiedeleut branch. As to the express affiliation trust, would a court have to interpret this, or could it just defer to either the majority judgment or the highest tribunal as to its meaning? If deference, Group Two again had both the majority position and had also retained affiliation with the other two tribes, while Group One had lost it. Therefore, if Group Two had claimed the property, rather than Group One, perhaps the deference model could have been used. The Hutterite Church had given its own interpretation to the affiliation and doctrinal trusts: it had deemed Group Two to be within the trusts and Group One to be without. Thus, the court should simply defer and enforce, if necessary, the decision of the Church. However, deference was not used because the whole claim of Group One - who actually brought the case - depended not on deference to ecclesiastical judgments, but rather on striking down those ecclesiastical judgments as violating express and implied Hutterian trusts.

A different argument might be that deference could not be used even if Group Two had brought a claim to evict Group One, which they would not do given their pacifist and anti-litigation religious convictions. But suppose they had. The strongest model of abstention would involve cases that are reciprocal. ${ }^{154}$ It does not matter which side brings the case; the court will simply not take it because to do so would entangle the courts with matters of religion, for which it has no jurisdiction. Thus, one might ask, even if the deference model allows courts to enforce express affiliation trusts, which higher body in the Hutterite context is the proper object of that trust? Given that the schism resulted in rival Schmiedeleut conferences, and in fact arguments could be made that the locus of Hutterite power beyond the colony was at the Conference level and not at the next higher level constituting the association of the three Conferences, the court could not simply enforce an affiliation trust without getting into further religious

In fact, the scope of the abstention doctrine may be questioned because cases which might have fallen into the abstention category, if brought by one faction or individual, often fall into the deference or neutral-principles categories when the shoe is on the other foot and the claim is to oust someone or a group from the property. For example, while abstaining from judicially reviewing the expulsion of members from a Baptist church, the Louisiana Court of Appeal still affirmed that an injunction could be granted to exclude the expelled members from the church property. See Macedonia Baptist Foundation v. Singleton, 379 So. 2d 269 (La. App. 1979). The Supreme Court of the same state in another case affirmed that the court could enforce the decision of a majority of a congregational church to terminate the minister when the internal law of the church gave such authority to a properly constituted meeting of members. An injunction, backed by the power of the state, would compel the terminated minister to abandon the pulpit. See LeBlanc v. Davis, 432 So. 2 d 239 (La. S.C. 1983). The Missouri Court of Appeals abstained from judicial review of a dispute over the control of a church because it dealt with an ecclesiastical matter. Yet, in the same case, when a Bank brought an interpleader motion to determine which of the factions was entitled to the funds in the church account, the court awarded the funds to the defendant, given that the lawsuit brought by the plaintiff group was dismissed for lack of jurisdiction. See Rolfe v. Parker, 968 S.W. 2 d 178 (Mo. C.A. 1998). Many more cases could be cited where the courts abstain from hearing a claim, but then, in effect, defer to one side and use the power of the state to enforce the claims by one side to control the property of the religious organization. This is not robust abstention. 
controversy as to which higher body was the proper authority to which to defer. Thus, even the deference model might fail, unless the courts simply classified the colony as congregational and deferred to the congregational majority decision on the meaning of the affiliation trust. However, there is no indication that the courts in these Hutterite cases would have taken a deference approach.

Clearly, the courts concluded that abstention was the only way in this context to avoid getting entangled in religious matters. Quoting from Poinsett, ${ }^{155}$ the court in Tschetter stated,

The court is unable to envision any set of facts which would more entangle the Court in matters of religious doctrine and practice. The religious communal system present in this case involves more than matters of religious faith, it involves a religious lifestyle. An individual Hutterian colony member's entire life - essentially from cradle to grave - is governed by the church. Any resolution of a property dispute between a colony and its members would require extensive inquiry into religious doctrine and beliefs. It would be a gross violation of the First Amendment and Supreme Court mandates for this Court to become involved in this dispute. ${ }^{156}$

One of the difficulties with American jurisprudence, however, is identifying the line between abstention cases, where the courts refuse to hear the dispute even when property or civil rights issues may be implicated, and those cases where the courts take jurisdiction when civil and property rights are sufficiently at stake and which can be decided by deference or neutral principles. If every property claim could be determined by the application of express affiliation trusts or by deference to the decisions of the ecclesiastical authorities, congregational or hierarchical, or by neutral principles, why are there abstention cases at all? Perhaps abstention is more likely to be taken in congregational settings where there are no higher ecclesiastical tribunals and wellestablished systems of canon law to which to defer? For example, in a case where a Plymouth Brethren congregation had a doctrinal schism, which involved twenty members excommunicating seventeen members and vice versa, the two groups shunning each other, and the Board of Trustees (to be elected by majority vote but subject to a very generally phrased doctrinal trust) being divided, the courts also expressed doubts that such a case could be decided on the basis of neutral principles. ${ }^{157}$ If there is an express doctrinal trust, it may be easier for a court to defer to the hierarchical decision on such matters than it is to defer to mere majority vote at the local level. Even disputes in hierarchical polities may involve issues of authority and membership that might lead a court to abstain rather than enforce ecclesiastical decrees.

At bottom, if a court cannot decide such cases without entering the territory of religion, it should abstain and leave the parties in the status quo mess in which they original].

157
Supra note 17.

Supra note 18 at 365, quoting Chief Judge Jones in Poinselt, supra note 17 at 543 [emphasis in

Clough v. Wilson, 358 A.2d 231 (Conn. S.C. 1976). The Court suggested that the trial judge who dismissed had not tried hard enough on the neutral approach. but the court agreed that in the end the trial judge might be right. 
have found themselves. The religious community should be left to resolve its own disputes without the coercive force of law. The abstention approach is the strongest example of protecting the sovereignty of religious communities, even if it also means that the internal law cannot be enforced with the aid of the state.

\section{CONCLUSION}

We have noted that Canadian courts will not simply defer to the ecclesiastical judgments of church authorities about membership issues without judicially reviewing those decisions to ensure that they conform with the internal law of the religious group. In addition, the courts will impose the procedural norms of natural justice on religious groups. ${ }^{158}$ We have noted as well that, in theory, the Canadian courts can interpret and apply both express and implied doctrinal trusts to resolve property disputes when membership alone does not determine the matter. There is supposedly no Canadian theory of the separation of church and state standing in the way of judges attempting to muddle through religious documents and entertain the conflicting testimony of religious experts. The church is just another voluntary organization like the stamp collectors club or the water polo club. ${ }^{159}$ The norms and practices of religious groups are like terms of a contract that bind the group together, and the court may interpret and apply these terms, as they do in the field of commercial contracts and other corporate documents. Canadian courts may not welcome the prospect of deciding which group of Hutterites will get expelled from "their" homes, but, in theory, the job of the courts is to resolve disputes, not toss them out because there is some other sovereign that has competing jurisdiction.

However, when we actually look at the performance of the Canadian courts - at least in the area of church property litigation - the gap between the American and the Canadian approach is not as wide as might be thought. Obviously, the American courts do take jurisdiction to resolve the vast majority of church property disputes and apply the coercive force of the law to enforce property entitlements to church property, though there are some cases that fall under the abstention category. Furthermore, the Canadian courts are actually increasingly breathing cross-border air and avoiding implied doctrinal trusts, as well as the exclusionary application of express doctrinal trusts, except in the most obvious and clear cases of departure. My review of the cases has shown that the Canadian courts actually have a long history of refusing to find breaches of doctrinal trusts and have been quite willing to conclude instead, sometimes over the objections of both factions, that both factions are still within the scope of the trust. Neither side can exclude the other on the basis of breach of doctrinal trusts. While this is not abstention, it may amount to the same result if a court sends both parties back to square one and refuses to expel either from the property.

We may well assume that a Canadian court would easily find that both Group One and Group Two are doctrinally within the "Hutterian Brethren" church. An outsider 
could visit any particular colony in Manitoba and not know which of the two groups it belonged to, unless he had a substantial store of background knowledge to see the subtle clues. While we might argue that Group One is departing from traditional Hutterite doctrine in bringing lawsuits against their own brethren, it is unreasonable to really think the Canadian courts are going to determine and add up the fundamentals of the faith and decide that Group One has 100 of them while Group Two has 101, or vice versa. Plainly, the two groups, in the sense of an organic trust, are still Hutterites in their identity and religious practices even if they have been bitterly divided over some issues. I doubt that a court would exclude one group or another from community property on the basis of the general doctrinal trusts. This is not a case of people leaving the Hutterite faith and then attempting to privatize the communal property of a Hutterite colony by claiming a pro rata share upon leaving or being expelled. This is not a switch in religion, but rather a schism within one religion.

The enforcement of affiliation trusts, express or implied, as the basis for allocating property entitlements is more likely, however. Here, it is arguable that the Group Two faction at a colony in schism would have a strong claim to be entrusted with all the assets even if Group Two were a minority. The Hutterian Brethren Church - that is, the highest level union of the three Leuts - has recognized and accepted that Group Two is the legitimate successor to the Schmiedeleut and is the group that is part of the body with which the colony is supposed to be affiliated, namely the Hutterian Brethren Church. Even with the express affiliation trust, a court might find that both groups are within the scope of the trust by accepting the argument that "Hutterian Brethren Church" is a concept wider than the church as constituted by those who have signed the new Constitution. The Group One Schmiedeleut Conference also has a constitution that claims it is the Hutterian Brethren Church. Furthermore, one may seriously doubt that any court would want to set a precedent that proclaimed that half of the Hutterite colonies in Manitoba - namely all the Group One colonies - must be given over to the other half - Group Two Hutterites. While litigation was indeed brought by Group One loyalists at particular colonies in schism, I doubt that even Group One could possibly desire a judicial remedy that sent half the Hutterites in Manitoba into the streets with nothing but the shirts on their backs. Courts are no longer blind to consequences in the name of fidelity to legal principles.

The American abstention idea - that the courts should simply leave the Hutterites in whatever schismatic state they are in at any colony - actually appeals to me. Even a Canadian judgment that finds both sides of the dispute to be within the doctrinal or affiliation trusts is still a secular judgment on matters of religion over which we may seriously doubt that outside courts should tread. From within the Hutterite religion, Group Two may well argue that Group One has adopted liberal views on lifestyle issues that have placed Group One outside the proper sphere of Hutterite faith. Who are we, as outsiders, to say that they are wrong? From within the Hutterite religion, on the other hand, Group One may argue that an Elder cannot be removed, but has the office for life, and thus Group Two has fallen from the church. Who are we to say that they are wrong? 
Finally, if a court really must decide a case, the all-or-nothing remedy in the face of a schism is not very appealing. We might well consider whether a pro rata division of property might be an alternative worth developing in the common law as a way of resolving certain kinds of church property disputes. Not unlike the presumption on the equal division of marital assets after separation and divorce, could we not view some religious groups from an organic, rather than a doctrinal perspective, and when relationships are broken assume we should divide the marital assets, as it were? Obviously, this prospect requires a great deal of further elaboration as to what factors in church property disputes would or would not make such a remedy appropriate, but that is a topic worthy of further consideration. Such an approach would have its own difficulties. Obviously, if departing Hutterites could in effect privatize communal property by getting some share that was then owned as private property, the whole communal property scheme of the Hutterites might be destabilized. If done legislatively the Hutterites would likely bring action claiming that such a scheme violated their Charter rights to freedom of religion. The issue is no less real if such an approach were adopted judicially as part of the common law, rather than by way of legislation. However, if both groups, even though in dispute over some issues, are still plainly committed to living in Hutterite colonies, where no one owns anything, the remedy of division might be appropriate. Communal property would not be privatized by the court, but rather communal property would remain communal property, and would be divided between Hutterite groups. It might also be appropriate in other more common church property disputes, where factions fight over the style of worship, over some doctrinal point, or over affiliation issues when no clearly worded trust can resolve the matter. 